\title{
Limits to learning: the struggle to adapt to unintended effects of international payment for environmental services programmes
}

\author{
Dirk-Jan Koch ${ }^{1}$ (D) Marloes Verholt ${ }^{1}$
}

Accepted: 6 July 2020 / Published online: 15 July 2020

(c) The Author(s) 2020

\begin{abstract}
This article pioneers new thinking on learning by organizations created by international environmental agreements, especially the boundaries within which learning can take place. It hypothesizes that there are ideological, institutional and technical boundaries to learning, which negatively impact the effectiveness of international environmental programming. This theory is rigorously tested by applying it to a group of new programmes, the forest-focused payment for environmental services programmes, which find their origin in the United Nations Framework Convention on Climate Change. The article systematically researches unintended effects of these programmes and clusters them into four categories. The uncovering of these unintended effects leads to the main research question: do international organizations actually succeed in adapting to these unintended effects? By combining three methods (a structured literature review, a systemic internal programme document analysis and expert interviews), the research finds that organizations struggle to adapt to these unintended effects. Whereas some of the limits to learning can be overcome by enhancing technical capacities, other limits, notably those that are induced by ideological thinking and institutional imperatives, are hard to overcome.
\end{abstract}

Keywords Payment for environmental services · Unintended effects · Policy learning · Bounded policy learning $\cdot \operatorname{Redd}+\cdot$ International organizations

\section{Introduction}

There has been a strong rise in the number and size of payment for environmental services programmes in the world (Ezzine-de-Blas et al. 2016), and this number is set to increase further as countries start to increase their funding for climate change mitigation activities (United Nations Framework Convention Climate Change, UNFCCC 2018). There are payments for environmental services as diverse as watershed management, marine resources

Dirk-Jan Koch

d.koch@maw.ru.nl

https://www.ru.nl/personen/koch-d/

1 Radboud Social Cultural Research, Radboud University, Montessorilaan 3, Postbus 9104, 6500 HE Nijmegen, The Netherlands 
management, biodiversity management, and forest management. This research focuses on forest management, as here payment for environmental services is now in vogue and donors are channelling hundreds of millions of dollars into these programmes via, for instance, the World Bank's Forest Carbon Partnership Facility, and the Reducing Emissions from Deforestation and Forest Degradation (REDD+) programmes of the United Nations (Bayrak and Marafa 2016). These programs were initially proposed by international environmental agreements, notably the United Nations Framework Convention on Climate Change.

This article contributes to two strands of literature. First, it contributes to the literature on the effectiveness of climate change mitigation programming, notably the effectiveness of payment for environmental services (PES). Whereas there is quite some literature on whether PES programmes achieve their intended effects (Duchelle et al. 2018), this research focuses on the unintended effects of these PES programmes. While in the broader development studies literature these unintended effects are regularly ignored, they can have a major impact on both intended effects in the long run and other broader development objectives (Koch and Schulpen 2018). The second strand of literature to which this research contributes is the literature on the management of unintended effects. Though there is a nascent focus on unintended effects in the development and international relations literature (Burlyuk and Noutcheva 2019), little attention is paid to how organizations aim to mitigate unintended effects (Koch and Burlyuk 2019).

International civil society organizations have lambasted the PES approaches in the area of forest management, notably the REDD+ programme. The REDD+ programme is the first global programme to use a PES approach. New organizations have emerged subsequently, such as the REDD-Monitor. These organizations argue, amongst other things, that REDD+ programmes contribute unintentionally to (carbon) accumulation by dispossession, as indigenous groups rarely have title deeds and are hence not adequately compensated by these types of programme, while their access to their forest is reduced (REDD-Monitor 2011). These organizations have popular backing, and climate March demonstrators are regularly seen holding 'No-REDD' posters.

The objective of this research is to contribute to insights into how the effectiveness of PES programmes can be enhanced, notably by reducing unintended negative effects. Therefore, the three research questions that guide our research are: (1) What are the unintended effects of PES programmes in the area of forest management? (2) Are organizations dealing with these unintended effects? and (3) What is preventing organizations to adapt better to unintended effects? This research used three main research methods to gather information on its main research question: a structured literature review, systematic policy document analysis and key stakeholder interviews. The three methods provided complementary information and allowed the possibility to triangulate the results.

The structure of this article is as follows. Firstly, a theoretical background is provided on the key concepts of this article, notably unintended effects and their management (Sect. 2). Secondly, an overview of the methods used for this research is presented (Sect. 3). Thirdly, the results of the systematic literature review are described and clustered into four types: (1) motivation crowding effects; (2) marginalization effects; (3) leakage effects and (4) migration effects (Sect. 4). Subsequently, the article offers an analysis of how organizations that are funding and rolling out these types of programme are dealing with these four types of unintended effects (Sect. 5). The paper concludes by discussing the results of this research. It aims to highlight the potential underlying mechanisms that contribute to explain why unintended effects are being dealt with the way they are. In the conclusion, both academics and practitioners are provided with suggestions for better consideration of unintended effects in PES programming. 


\section{Theoretical background on (management of) unintended effects}

The term 'unintended consequences' was first coined by the sociological functionalist school. In this school of thought, an unintended consequence refers to a particular effect of purposive action which is different from what was wanted at the moment of carrying out the act, the desire for which was the reason for carrying it out (Baert 2016). This definition is also used in this research. There are at least seven ways of classifying unintended effects (Koch and Kinsbergen 2018), yet two elements are of particular importance for this research as they impact the management of these effects (which are of key importance for our second research question on how organizations aim to manage the effects): the degree of anticipation and the degree of avoidability of these effects.

\subsection{Unintended but anticipated?}

One misconception about unintended consequences is that they are unforeseen, unanticipated, yet this is often not the case: consequences that are not intended by the actor might very well be anticipated. However, because those consequences are deemed to be of less impact or low probability (or both), the programme is executed regardless, or in such a way as to minimize unintended negative consequences. De Zwart (2015) argues that these unintended consequences are not a consequence of what Merton (1936: 901) calls "ignorance or error", but a result of protracted deliberations on intervention dilemmas. A first step for organizations to manage unintended effects is to ensure that they anticipate potential unintended effects.

One school of thought, complexity or system thinkers, has serious doubts about the degree to which unintended effects can be anticipated. They argue that there is a multitude of interconnections, non-linearities, multi-dimensionalities and unpredictabilities that interact with external interventions. These complexities render it difficult to understand the potential ambiguous effects of external interventions in integrated systems (Brusset et al. 2016). In our analysis of how organizations manage unintended effects, we are hence first analysing the degree to which the unintended effects were actually anticipated.

\subsection{Unintended yet avoidable?}

Even if organizations were to succeed in anticipating unintended effects, there is a serious theoretical debate as to whether unintended anticipated effects can actually be avoided. Again, this debate pitches the more development management-oriented thinkers against the complexity thinkers, or the "planners versus the searchers" (Easterly 2006: 1). The literature that builds on Merton (the 'planners') suggests that unintended effects could be avoided by more thoughtful planning and better monitoring and adaptation.

Thinkers-the 'searchers', who are more inspired by complexity thinking-argue, for the same reasons that the unintended effects are often unanticipated, that unintended effects are often so-called double effects (de Zwart 2015). Double effects are akin to collateral damage in the military sense: while the interveners can do their utmost to minimize them, there will be always a second effect: hence the term 'double effect.' This is unavoidable.

One group of authors does not take the avoidability or unavoidabilty of unintended effects as a given (Morell 2010: 25, 45). In the second part of this research, which focuses on the management of unintended effects, we will also revert to the question of whether results are (considered) avoidable. Unavoidable effects cannot be managed, but avoidable 
effects can: therefore, classifying effects along this line is also relevant to answer our main research question.

\subsection{Managing unintended effects: bounded policy learning}

If unintended effects are foreseeable and avoidable, the question is: Will organizations actually adapt their programming to unintended effects? Will organizations 'draw lessons'?

This article builds on the line of thought that drawing lessons with respect to unintended effects takes place within certain clear limits or boundaries (cf. Koch and Burlyuk 2019). Until now, a clear theoretical overview of these potential boundaries to policy learning is largely missing, and this article proposes a more comprehensive approach to bounded lesson learning. Authors are currently focusing on specific limits to learning, but have been less convincing in providing an encompassing taxonomy for these limits. While some authors have focused on technical issues, such as a lack of information that prevents lesson learning (e.g. Eising 2000), others have focused on political barriers (e.g. Radaelli 2009), and still others have emphasized ideological obstacles (e.g. Sabatier 1988). This article therefore aims to contribute to a comprehensive nomenclature for the bounded policy learning concept. This article hypothesizes that there are at least three impediments that hamper drawing lessons: technical, institutional and ideological.

Technical obstacles are those barriers formed mostly by incomplete information. The bounded rationality literature from the economics discipline provides backing for this by highlighting the cognitive limits of human beings' and organizations' ability to process information (e.g. Eising 2000). Better measurement techniques and better-organized feedback loops could enhance learning of policy makers; not online because of their own improved (access to) information, but also because the people and institutions holding them accountable will be better informed. Arguably, access to information is influenced by socio-economic status and power, hence the status of an individual, group or policy institute influences its ability to learn.

Institutional limitations to policy learning are those obstacles that result from organizational pressures and institutionalized interests. Learning is used to maintain a specific regulatory policy paradigm, and not necessarily because there is a desire to deliver optimal solutions. Therefore, Radaelli (2009) argues that learning is limited by institutional imperatives. If policy learning implies that certain organizational or institutional interests will be undermined, these potential lessons will be discarded.

Ideological barriers are different from technical and institutional barriers as they are the result of deeply ingrained values that contribute to tunnel vision. Sabatier (1988: 150) argues that the main obstacles to learning are ideological, as he stipulates that "acknowledging failure and learning from it would entail fundamental rethinking of core and ideological values, which is unlikely". People and organizations unknowingly employ perceptual filters which prevent them from internalizing information indicating policy failure.

In the second part of the research on the management of unintended effects, we contribute to a better understanding of the boundaries to policy learning by systematically applying the nomenclature developed for this research to unintended effects of PES programming. Our hypothesis is that no one of the boundaries prevails, but they can all exist simultaneously. Understanding the limits to learning is pivotal, as it will indicate whether there is a likelihood that these barriers to learning can be overcome. 


\section{Methodology}

\subsection{Structured literature review}

We performed the systematic literature review through an elaborate keyword search. To increase the relevance and coherence of the analysis, we used the following inclusion criteria (1) the publication had to concern primary research; (2) the publication had to analyse at least one unintended effect; (3) the publication had to focus on unintended effects which had already taken place and were not a prediction; (4) the publication had to concern PES schemes in low- and middle-income countries (LMIC) ${ }^{1}$ only; and (5) the publication had to be relevant for forest conservation PES. More details on the methodology for the structured literature review can be found in "Appendix 4".

\subsection{Policy document review}

The literature review of mostly academic analyses yielded results from individual PES projects in LMIC countries across the globe. Although the first local PES projects were started in the 1990s, global initiatives to reduce deforestation gained traction in the first decade of the 2000s. In 2008, REDD+ was launched by the United Nations. The next step of this research is to analyse if and how REDD+ as a global initiative has taken stock of the negative effects of earlier PES projects. To this effect, we executed a document review of the two main global programmes that implement REDD+ : the Forest Carbon Partnership Facility (FCPF) of the World Bank and the Green Climate Fund (GCF). After a quick scan of the available documentation, we analysed the documents that engaged with unintended effects. These included, when available, safeguard policies, indigenous peoples policies, environmental and social standards, funding proposal templates and independent evaluations. Furthermore, as both the FCPF and the GCF have now signed their first contracts with countries receiving results-based payments, we also analysed the available documentation for the countries that were most advanced in their implementation (notably the Democratic Republic of Congo (DRC) and Mozambique for the FCPF; and Ecuador for the GCF). This included strategic environmental and social assessments, environmental and social management frameworks, assessments of REDD readiness, and progress reports. An overview of the consulted literature can be found in "Appendix 2".

\subsection{Key informants: interviews}

We subsequently held ten semi-structured key informant interviews with a variety of stakeholders, each lasting between $40 \mathrm{~min}$ and $1.5 \mathrm{~h}$. These sought firstly to confirm the results of the literature and document reviews, and to gain first-hand information on how unintended effects are anticipated and managed, and what difficulties are encountered in these processes. Secondly, the key informant interviews shed light on the boundaries to policy learning. We held interviews with staff at the FCPF and GCF, as well as an independent researcher on REDD+ in the DRC, a professor on land use systems, and policy staff at the

\footnotetext{
${ }^{1}$ See Organisation for Economic Development Cooperation list of Official Development Assistance recipients: https://www.oecd.org/dac/financing-sustainable-development/development-finance-standards/DAC List_ODA_Recipients2018to2020_flows_En.pdf.
} 
Table 1 Frequency table of encountered unintended effects of PES programming in literature review

\begin{tabular}{lc}
\hline Effect & \# studies \\
\hline Motivation crowding & 17 \\
Marginalization & 14 \\
Indigenous peoples & 13 \\
Conflict & 5 \\
Leakage & 8 \\
Migration & 6 \\
Total & 63 \\
\hline
\end{tabular}

Dutch Ministry of Foreign Affairs and Ministry of Agriculture, Nature and Food Quality. For more details on the key informants, please consult "Appendix 3".

\section{Literature review results: unintended effects of PES are manifold}

The literature search led to a total of 57 documents (see "Appendix 1" for an overview of all documents). These included 48 journal articles, five working papers and four doctoral dissertations.

We distinguished whether unintended effects were found in the target population (i.e. participants in PES schemes or targeted forests) or outside the target group. This is relevant, as monitoring activities initially may just look for results or effects in the target population. Effects found outside the target population are eminently relevant to see what additional monitoring criteria could be useful for PES designers and implementers. In total, we found 41 effects in target groups and six effects in other groups. Ten studies found effects in both groups.

On the basis of the documents found, we categorized the effects in four thematic areas: (1) motivation: whether participation in PES programmes changed participants' intrinsic motivation to engage in environmental conservation; (2) marginalization, as PES is mostly availably to landowners only, potentially denying poorer people any potential benefits of the scheme; (3) leakage: whether PES and increased conservation activities in one region led to decreased conservation activities or simply more deforestation in other areas; and (4) conflict: for example, over property rights, land use rights and other issues of who has access to what. See Table 1 for an overview of the effects found per thematic area. Some studies dealt with multiple effects and are thus counted twice.

\subsection{Motivation crowding}

A total of seventeen studies found unintended effects related to motivation crowding. Research on motivation crowding effects is rooted in behavioural sciences/behavioural economics and aims to establish a relationship between economic incentives and social preferences. By issuing rewards and punishments, PES programmes can alter community members' intrinsic motivation (Bowles and Polania-Reyes 2012). This could be attributed to “(1) putting a price on conservation effort, (2) signalling bad faith in villagers' intentions, and (3) reducing individual autonomy" (Andrews 2018: 101). As mentioned, we found 
motivation crowding effects in both target groups and non-target groups, but were mostly searched for in target groups by authors.

Six articles found that the monetary incentive of a PES programme altered participants' intrinsic motivation to engage in forest conservation. Participants' moral and altruistic basis for forest protection was found to be (partially) replaced by the desire for incentives. This raises questions regarding the sustainability and long-term effects of PES programmes (Isyaku 2017). Moreover, one study found a positive relationship between the length of the programme and the decrease of utilitarian/monetary reasons to participate, as well as an increase in intrinsic reasons (García-Amado 2013). This is interesting to take into account in the programme planning phase. Motivation seems to shift towards the utilitarian side, moreover, depending on the amount of the payments received (Asbjornsen et al. 2017).

The study by Alpízar et al. (2017) asserted that imbalances in motivation are in fact a root of ineffective, or less effective, PES. PES schemes tend to include those who are already motivated to contribute to environmental conservation, but fail to include the big polluters. Additional efforts to include big polluters led to a decrease in motivation among those who were already positively contributing (Alpízar et al. 2017). Other findings, putting PES projects into a wider social perspective, suggest that payments help raise participation in conservation projects where people are otherwise uninterested, but that participation in communal tasks can be high irrespective of the incentive if social norms favouring participation are present. In Tanzania, high individual payments did not undermine participation, although they appeared to reduce people's satisfaction from the task relative to when there is no payment (Kerr 2012). In Mexico, group payments made through village authorities yielded lower participation where people distrusted leaders (Kerr 2012).

\subsection{Marginalization}

A total of fourteen documents analysed general marginalization-related effects. Such effects incorporated a number of issues, including food insecurity, exclusion of customary institutions, lack of livelihood alternatives, reinforcement of existing social differences, eroding of community organization, undermining of traditional farming practices, and perpetuating inequalities in resource access. These effects do not seem to be confined to a specific region, but were found in a wide variety of countries including Mexico, Ecuador, Bolivia, Tanzania, Kenya, Vietnam, the Philippines and Indonesia.

We found land tenure issues in multiple studies, as PES schemes tended to focus on landowners as their main participants, excluding poorer households from any benefits through the scheme. We found these issues were prominent in various countries, where projects risk being exclusive of the rural poor and sometimes specifically of women (Vardhan and Catacutan 2017) and thus, in terms of their poverty alleviation goals, do not reach those who need them most. Lansing (2014) suggests that efforts to include the local poor can be effective but have to be cognizant of the barriers to participation for smallholders, which can vastly differ between, and even within, countries. These barriers can be procedural (fair inclusion in political processes), distributional (equal sharing of costs and benefits, burdens and rights) and contextual (power dynamics and access to information), as shown by Vardhan and Catacutan (2017) in their analysis of gender and social equity in PES in five countries in southern Africa and southeast Asia. 


\subsubsection{Marginalization: indigenous peoples}

Negative effects on indigenous peoples (IPs) are a form of marginalization that deserves extra attention. Indigenous populations are widely thought to be at risk of discrimination through PES programmes. One of the main sources of discrimination is arguably the issue of land rights, as indigenous populations often do not recognize individual claims to land but take care of it collectively. Without attention to this issue in the design phase, a programme risks discrimination against people who can play a crucial role in the conservation of forests (Cotula and Mayers 2009). In the early days of PES and before REDD+ started, authors warned that PES programmes could risk violations of customary land and property rights, unequal and unfair cost-bearing of indigenous peoples for forest protection, land conflicts and conflicts among indigenous peoples over acceptance or rejection of PES schemes, increased state control over forests and exclusionary models of forest conservation, among others (Griffiths 2007). Likewise, Mayers warns that PES programmes could to more harm than good if social justice is not brought centre stage (Mayers 2006).

A number of studies confirmed these hypotheses: we found a total of thirteen studies substantiating how IPs are marginalized or discriminated against as a result of PES programmes.

One of the most common causes of marginalization of indigenous peoples lies in tenure insecurity-more specifically, the inability or unwillingness of governments to recognize and protect communal land rights, as many indigenous peoples do not wish to individualize tenure rights. In Mexico, moreover, by agreeing to conservation measures that restrict the use of ancestral agricultural land and prohibit hunting, food security decreased, causing a dependence on external food supplies (Ibarra 2011). In Ecuador, REDD+ was found to be at odds with IPs' plans for the protection and consolidation of their traditional territories, which are threatened by illegal logging and mining, oil extraction, and inclusion within national parks (Erazo 2013).

Authors also criticize the PES approach to conventional prosperity, arguing that this does not resonate with local perceptions of ecological sustainability, (social) welfare (Pokorny et al. 2013) and environmental justice (Martin 2014). Other causes of discrimination are more practical: a survey among indigenous populations in Ecuador showed that more than half of the respondents did not know their community was receiving incentives in exchange for their participation, or how these incentives were communally managed. Although over half of the respondents knew their community was receiving benefits, about the same number of people did not see any of these benefits reaching their families (Krause 2013). Some communities felt pressured to participate, albeit involuntarily, as a result of top-down power play (de Francisco and Boelens 2014).

\subsubsection{Marginalization: social tensions and conflict}

A total of six studies noted that PES schemescaused social conflict and irregularities. Sometimes these were related to land tenure issues, as mentioned above; in Mesoamerica (Guatemala, Nicaragua, Mexico, Belize), unclarities regarding property rights and social tensions around access to forest resources caused conflicts among participants and nonparticipants (Corbera et al. 2007). In China, social tensions were also rooted in tenure rights and led to significant delays in programme implementation (Gong et al. 2010). In Ecuador, conflicts concerned the financial management system and benefit-sharing mechanism of the project (Krause 2013). 
Sikor and Cầm researched the relationship between REDD+ and social conflicts in Vietnam. Taking a forest justice approach to analysing matters of conflict over forest and ideas of what just forest management would look like, they found that such local discussions are very difficult to translate into coherent PES policies on the international level (Sikor and Cầm 2016). Mahanty et al. (2013) also found that claims to forest carbon were complicated by ambiguities and complexities surrounding rights to forest land. Claims to forest carbon arguably emerge from a contested property arena in which knowledge, institutions and power relations all play a role. Affirmative actions to include vulnerable populations have not always yielded better results, however, such as in Nepal, where social tensions emerged regardless (Saito-Jensen 2014).

\subsection{Leakage}

Eight studies found leakage effects as a result of PES projects. Leakage can be defined as "the unintended decrease or increase in greenhouse gasses benefits outside of an intervention boundary that is either directly or indirectly attributable to the intervention implemented within those boundaries" (Atmadja 2012: 313). According to this definition, leakage can be both direct and indirect. Direct leakage is emissions increase caused by project activities - for example, when logging is banned from one area and as a result increases in a neighbouring area. Such direct leakage can also occur inside project boundaries: for example, when deforestation rates increase on other lands that belong to PES recipients. Indirect leakage can happen when loggers banned from an area switch to different activities that are also polluting, such as mining. Another form of indirect leakage happens through market mechanisms: where there are high levels of programme participation, general wealth effects result in increased demand, or supply reduces because of limitations on the amount of land available for agriculture (Alix-Garcia et al. 2012). Studies conducted in Panama, Bolivia, Indonesia, Malawi and Mexico found at least one type of leakage. Conditions decreasing leakage include a large price elasticity of agricultural products; small amounts of land initially indicated for sustainable tree products; small amounts of land taken away from agricultural production; an exchange of land for labour; the voluntary nature of participation; and strong social capacity through NGOs and community investments around protected forests.

\subsection{Migration}

Seven studies found negative effects of PES programmes on people's ability to live and work on their land, resulting in out-migration. Interestingly, four of these seven studies were conducted in China. Démurger and Wan (2012) found that a sloping land conversion programme had a profound effect on labour migration in rural China, where young, male and ethnic Hui individuals were more likely to be impacted by the programme. Overall, migration probability increased by $17.5 \%$ for participants versus non-participants. Also Zhang et al. (2018) found cropland abandonment and an increase of out-migration to cities as a result of two PES programmes in China. Interestingly, however, outward migration was found to decrease poverty, as migrants sent remittances back home. Other migration effects were found in Mexico and Lesotho. In Mexico, dietary diversity, agricultural practices, household economies and livelihoods were negatively affected by the preservation scheme, resulting in a de facto displacement of people from their communal lands (Ibarra 2011). In Lesotho, a project allegedly caused the displacement of thousands of people; the 
destruction of thousands of hectares of arable and grazing land; and the destruction of valuable communal assets. The payments through the compensation scheme were found to be both inappropriate and inadequate (Mwangi 2007).

Just one study found increased in-migration as a result of PES: in the Lac Mai Ndombe province in the DRC, one of the overlooked unintended effects of a PES programme was increased in-migration as a result of higher agricultural productivity (one of the objectives of the programme) (Gauthier 2018).

This literature review has shown that numerous unintended consequences in a wide variety of geographical locations have resulted from PES programmes and are thus a factor to be taken into consideration in REDD+. However, it is debatable whether the term 'unintended consequences' depicts the complete picture accurately. According to a fund manager at the FCPF at the World Bank, these effects are by now all well known, and are mitigated and minimized to the best extent possible: as such, if present they are still unintended, but anticipated (interview 2). The next section of this paper analyses whether this is actually likely to be the case, and whether the effects distinguished in the literature review are in fact anticipated, mitigated and learned from by REDD+ implementers.

\section{Results: boundaries to learning-technical, institutional and ideological}

The most important way in which the funds seek to mitigate unintended consequences is through developing safeguards and monitoring them. These safeguards were agreed by the United Nations Framework Convention on Climate Change (UNFCCC) in 2011 and aim to mitigate and minimize social and environmental risks and harm (UNFCCC 2011). All REDD+ funds have taken these as a starting point and built upon them to address a wide variety of risks (World Bank Group 2017). Below, per effect (as identified in the literature review), the ways of anticipating, monitoring and learning from these risks are outlined and analysed.

\subsection{Motivation crowding: ideological constraints to learning}

Of all the effects, motivation crowding is the least noted in policy documents. Motivation crowding is the object of neither safeguards nor of any official guidance, although in the programme design phase applicants do have to think through how to prevent reversal at the end of the programme, which could include reversal caused by motivation crowding (UNFCCC 2011: art. 2f; GCF 2017; World Bank BIO Carbon Fund 2017). There is no further specification of motivation crowding in the policy and programme documentation. However, according to interviewees, it is in fact a well-known risk that is being managed in various ways, and lies at the core of the programme design rather than in monitoring. According to one interviewee from the World Bank (interview 1), the structure of the benefit-sharing mechanism ${ }^{2}$ mitigates this risk by having as its core aim to help landowners

\footnotetext{
${ }^{2}$ Benefit sharing can be understood as "allocating, administering, and providing benefits to multiple actors for certain activities or results through some form of positive incentive, opportunity, payment, rent/profit, or other compensation - whether financial or non-monetary" (Hite 2015: 1). In REDD +, this concerns the way in which the benefits of sustainable forest management are understood and shared by communities, governments and other stakeholders alike.
} 
sustainably decrease the pressure on forest lands. This is done not only through financial incentives, but most importantly through capacity building and knowledge sharing. The carbon payments are "the icing on the cake", but are arguably "too small to have to have an influence on motivation; they are a long way from being sufficient to sustain a family" (interview). Hence, PES programmes assume that landowners or communities do have an intrinsic motivation to work towards sustainably using their land, as they benefit from that achievement in the long term (interview).

The FCPF realizes, in line with García-Amado's findings (2013), that the risk of motivation crowding will increase with short programmes, as they will less likely reach a level of development than can be sustained by the participants themselves. They do account for this in their programme design and advising of implementers (interview 1); however no official guidelines have been developed accordingly as yet In addition, an issue that relates to motivation crowding is that programmes do not reward those who have already taken action on either individual/community or state levels. The FCPF fund manager calls this a perverse consequence: with good behaviour not being rewarded (i.e. on the country level, emissions might already be lowered and difficult to reduce further), you also risk motivation crowding. Although the World Bank is well aware of this issue, it is very difficult to manage (interview 2).

Despite the efforts to manage this effect, it is questionable whether it is possible to completely nullify its risk in a system that has at its core the commodification of natural resources and rewarding those who engage in stewardship. Arguably, motivation crowding is a so-called double effect (De Zwart 2015): these are unavoidable, often unintended but anticipated, and negative. De Zwart asserts that double effects are akin to collateral damage in conflict, where achieving the end goal justifies the means and infliction of a certain amount of harm or loss. This also suggests that boundaries to learning from these effects are rooted in the ideological base of PES and REDD+. As long as the neoliberal, rewardsbased nature of these programmes does not change, motivation crowding will likely be a consequence to be reckoned with.

\subsection{Marginalization: institutional boundaries to learning}

All the reviewed programmes have a safeguarding system in place that aims to prevent marginalization more than any other effect, as arguably any form of social or environmental disadvantaging of an individual or group is a form of marginalization. As such, marginalization is the most noted risk in the policy documents of all funds. As marginalization can occur in a wide variety of forms, all funds have paid attention to preventing and mitigating such effects. In doing so, they have taken the UNFCCC safeguards as a starting point and developed additional mitigation measures for social and environmental harm done through the programme. The UNFCCC safeguards include "Respect for the knowledge and rights of indigenous peoples and members of local communities" and "The full and effective participation of relevant stakeholders" (UNFCCC 2011: 4, 13). The World Bank added safeguards on access to information, indigenous peoples and natural habitats, among others (World Bank FCPF 2013). The GCF is in the process of developing additional safeguards, which should include labour and working conditions, cultural heritage, and communal health and safety, according to the internal documentation of the Dutch Ministry of Foreign Affairs. 


\subsubsection{Indigenous peoples}

As mentioned, IPs' rights are accounted for in the safeguarding policies of all programmes. In addition, the GCF adopted an Indigenous Peoples' Policy in 2018, informed by submissions of 105 indigenous peoples' organizations and support groups. The FCPF, moreover, has an indigenous peoples' dialogue process and a capacity building programme for IPs and civil society more broadly (FCPF n.d.). The governance structure of the FCPF also includes both civil society and IPs, who hold observer status and attend stakeholder consultation meetings. Furthermore, country programmes need to have regular stakeholder consultation meetings: generally, their attitude towards REDD+ has become more positive over the years (Riamit 2019). However, funds do need to be kept on their toes when it concerns land rights and marginalization occurring because of unclarity, inconsistencies or unfairness regarding who has a legitimate claim to a particular piece of land, for example. Although the FCPF requires a land tenure analysis pre-programme, including a plan for mitigating problems, IPs' organizations have been very critical in the past and will likely continue to be so when they think their rights and livelihoods are at stake (Reed 2011).

\subsubsection{Conflict}

The funds are aware that conflicts can result from poor management of a programme, and try to anticipate this in the programme design. The FCPF is very well aware that when a public space is privatized, its value increases, and people will try to profit from it at the expense of others. The FCPF tries to tackle this through participatory forest management, where both the responsibility and the benefits of preserving forests are shared equally among a variety of stakeholders. In addition, the Feedback and Grievance Redress Mechanism should compensate for any form of marginalization through the programme, and in particular for conflicts that have not been adequately anticipated. This is a requirement for any national or sub-national REDD+ programme and is part of the methodological framework (FCPF Methodological Framework: criterion 26). The GCF also has a grievance mechanism, as laid out in the environmental and social policy (GCF 2018).

Although the effects mentioned above are different in nature, they are managed through one process, so we analyse this process only once. According to a fund manager at the World Bank, one of the goals of the first phase of REDD+ (REDD readiness) has indeed been to detect unintended consequences and to design and implement policies to address them. As such, now that the first contracts for results-based payments have been signed, an extensive system is in place from the start to minimize the risks of unintended consequences. Although the proposal of a country for results-based payments through REDD+ starts with a strategy to reduce GHG emissions, this has to be accompanied by a countrytailored risk section, benefit-sharing plan, strategic environmental and social assessment, environmental and social management framework, and grievance redress mechanism. These documents undergo various quality checks by the World Bank, donors and a technical advisory panel (interviews 2 and 3). When a country does not follow the safeguarding requirements, it is in breach of the contract. In case of minor issues, requests for improvement can be made. In a worst-case scenario, the funds can decide to cancel the contract; however, the implementation of REDD+ is in such a premature stage that this cannot yet be evaluated. In addition, the structure of results-based payments is another incentive for countries to comply with the contract: when results are not achieved, no payments are made (interviews 3 and 4). 
At the same time, according to some informants, there is a fundamental difference of opinion as to whether a programme should even start when there is still some risk of unintended effects, or whether all risks should be completely mitigated before the start (interviews 1, 6 and 7). The question is whether the latter is possible at all, with programmes engaging with tens of thousands of people. At the end of the day, when a programme does achieve the planned reduction in carbon emissions and doesn't achieve substantial poverty alleviation goals, one might still call it successful (interview 1). This is confirmed by an informant at Wageningen University, who asserts that precisely because REDD+ was borne out of the climate agenda, its climate goals will always prevail over unintended social consequences. When PES projects, such as some implemented by NGOs, take social and poverty reduction goals as their main objective, barely any effect is seen on forest levels (interview 7). This suggests an institutional boundary to policy learning, as from a donor's perspective, too, the main emphasis will be on the climate objective of REDD+, and some unintended social consequences are practically unavoidable. One representative of a local organization (interview 10) also stated that often the donor cannot come to visit the field program, because of security concerns. Therefore, they don't experience (and learn from) the unintended effects, such as conflict (interview 10).

Moreover, several informants confirm a level of spending pressure within the funds, particularly with bilateral donors who want to show results to their parliaments and constituencies (interviews 1, 2, 3, 6 and 7). However, they are also clear that the funds do not want to risk reputational damage because of this. Implementing a programme at the expense of the people who should benefit from it would undermine the entire programme, and is thus a risk the World Bank is not willing to take (interview 2). This issue was not recognized by a GCF informant (interview 4), but did become apparent in almost all other interviews. This issue of spending pressure suggests an institutional boundary to policy learning, where it is not only the donors who decide what they want to spend their money on, but also their relative electorates pressuring them to see results in the climate area, and less so in the area of social safeguards (interview 7).

\subsection{Leakage: technical boundaries to learning}

Leakage is recognized as a risk of REDD+ and is included in the UNFCCC safeguards, wherein parties should promote and support "actions to reduce displacement of emissions” (UNFCCC 2011: 2 g). Indeed, the FCPF Carbon Fund's methodological framework requires emission reduction programmes to be designed and implemented to prevent and minimize potential displacement. ${ }^{3}$ The risk of leakage must be assessed and labelled as high, medium or low, and risk mitigation strategies must be identified, prioritizing key sources of leakage. The programme must show implementation of this strategy and is invited to report on changes and lessons learned from the mitigation efforts (World Bank FCPF 2016: Sect. 3.5). Likewise, the BioCarbon Fund Initiative for Sustainable Forest Landscapes (a similar program to the FCPF) and GCF require a risk assessment for leakage as part of their programme document templates (World Bank BIO Carbon Fund 2017).

The BIO-CF, however, recognizes the difficulty of measuring leakage, as mentioned in an early programme evaluation study which proposes the simplification of leakage assessment (World Bank BIO Carbon Fund 2011). This is confirmed by an interviewee, who

${ }^{3}$ Leakage is called displacement in some of the policy literature. 
holds that it is very difficult, time-consuming and thus costly to validate that leakage is linked to a project, in particular when projects are not nationwide, which has been the case for many projects in the past (interview 1). Regardless of measuring leakage as part of the project, countries' reporting requirements under the Paris Agreement will show whether there is an overall increase or reduction in emissions. Although this will not lay bare any causal relationships, trends will be visible. As such, under the FCPF, leakage does not have to be measured, although the risks must still be assessed in the programme design. In addition, the fund has the goal to implement programmes nationwide and on a jurisdictional level, which makes leakage easier to detect. This is also the preference of bilateral donors. However, this is not yet feasible in all countries (interview 1).

The aim to scale up PES to country-level REDD+ is confirmed by an informant from the Dutch Ministry of Agriculture, Nature and Food Quality, who also asserts that this will allow the detection and thus better mitigation of leakage. In addition, because REDD+ works with results-based payments, there will be a strong incentive for countries to keep leakage to a minimum or make sure overall forestation targets are met regardless (interviews 3, 4 and 6). In addition, deforestation on a national basis is much easier to detectfor example, through satellite images of the area (interview 7). Hence, the boundaries to policy learning as regards leakage seem to be mostly technical.

\subsection{Migration: technical boundaries to learning}

Both the GCF (2018) and the World Bank (2017) recognise migration, and particularly involuntary resettlement, as an unintended consequence of REDD+. The Green Climate Fund asserts that GCF-financed activities will avoid or minimize the need for involuntary resettlement. When this cannot be avoided, a resettlement action plan must be negotiated in consultation with those affected. The resettlement policy framework should specify guidelines on how to deal with resettlement (GCF 2018). The FCPF environmental and social policies also aim to mitigate social or economic impacts from land acquisition or restrictions on land use by providing compensation for loss of assets and assistance to displaced persons to restore and improve their livelihoods and living standards (World Bank Group 2017).

Interviewees confirm this and furthermore explain that the land tenure assessment that is obligatory before each programme starts identifies whether migration is a risk that should be taken into account. At this stage, the strategy to mitigate this risk also has to be outlined on the basis of the social and environmental framework. "It must be taken into account, however, that REDD+ consists of big programmes that try to work with tens of thousands of people. There will always be a few who will not agree with your plans. The question then becomes whether you will negotiate until every single individual is on board, or whether you prioritize achieving results and start the programme nonetheless, with the risk of disappointing some and the hope of increasing traction" (interview 1).

Interviewees further assert that it is difficult to ascertain exactly what causes migration and whether this is a direct consequence of PES or REDD+. In Costa Rica, for example, the children of farmers moved to the cities as they did not want a future working the land. Their parents, who were left behind, saw a decrease in capacity to work the land. When a PES was started up, this was a way for the older farmers to maintain some income for land they would not be able to work anyway. As such, in this case, the migration came before the programme (interview 1). Interviewees indeed point towards the difficulty and costliness of finding out whether both inward and outward migration are a direct consequence of PES or REDD+. The capacity needed to find this out through household surveys or other intensive research methods is significant, and will reduce 
the amount of capacity and resources that can be dedicated to achieving the primary goals of REDD+ (interviews 1, 2, 3 and 7). In essence, therefore, these difficulties regarding the management of migration effects point towards a technical limit to policy learning.

\section{Discussion}

It is clear that international organizations have learned from the past and have developed measures to reduce some of the unintended effects. We found that learning has taken place especially in respect of negative unintended effects in the social realm (dubbed 'marginalization' in our research). Part of this learning is the result of active lobbying by advocacy groups, who are also found to have been effective in stimulating policy learning in other domains (Koch and Burlyuk 2019). Most of the learning was codified in safeguarding policies, but to determine if these safeguards are really upheld, continuous monitoring is needed. Yet, our results show that substantial barriers to learning also exist. These barriers are technical, institutional and ideological. While we think that some of the boundaries can be overcome, this is less likely to happen for some others, as further discussed in the conclusion section.

Some limitations to this research should however be noted. Firstly, the literature review was biased towards negative unintended effects, not taking into account the neutral or positive unintended effects of PES. This may provide a skewed overview of the unintended effects of PES programmes in general; however, the negative effects were more relevant for the research objective of this paper, which is policy learning. Secondly, we did not assess or rank the results of the literature review for quality, but merely used them to provide a general overview of negative unintended effects. Thirdly, the number of interviewees could have been expanded. Also, no fieldwork was done to engage first-hand with the unintended consequences and their mitigation strategies. Finally, one study (García-Amado 2013) pointed towards an inverse relation between programme length and the likelihood of unintended effects occurring. It would have been interesting to further research this programme length variable, however only a minority of the reviewed studies mentioned the length of the programme.

For future research, we would recommend diversifying the pool of interviewees and engaging in fieldwork to get to the bottom of which unintended effects are present in REDD+ and how these are viewed by various stakeholders-for example, through participatory action research. In addition, we engaged with REDD+ policymakers and implementers in a very early stage: the programmes are still being rolled out. Future research can focus more on how REDD+ is actually implemented and what unintended consequences are found some years after implementation. It could moreover further explore a possible programme length variable.

As regards the internal validity of this research, arguably the boundaries between the different types of unintended effects that we identified are somewhat artificial. For example, marginalization effects come in a wide variety of forms, but we chose to cluster them into one group because they are all managed through the same mechanisms (the social and environmental safeguards system). Even on that level, discussions could be held on what actually entails "marginalization" or "conflict" and how that should be interpreted or prevented from a funder's perspective. Also, the boundaries of the limits to policy learning are somewhat artificial and generalized; likely, multiple boundaries can serve to explain (parts of) a lack of policy learning with regard to most unintended consequences. However, they serve to explain the phenomenon of limits to learning, as well as the degree to which they can be overcome, and are useful to this end. 
A problem regarding external validity is that we translate negative consequences of PES programmes to the international REDD+ programme: it is possible that the effects found are very typical for a specific location or group and not necessarily generalizable at international policy level. In addition, we have identified limits to policy learning that are specific to international funds that implement REDD+. Caution must be taken when transferring our conclusions to other policy fields; however, it would nonetheless be useful to extract our findings and apply them to other entities involved with international climate policy making, particularly those concerning north-south funding streams. This could include for example the Global Environment Facility or the Adaptation Fund. The findings might also be relevant to international policy making on different subjects, as arguably organisational learning occurs and is hampered by similar factors across international organisations. New research could tap into these fields to more rigorously examine our theory.

Finally, because of the insufficient effectiveness of the current international climate action framework (Nordhaus 2015) there is an increased interest in climate clubs. Climate clubs are any international actor group that (1) starts with fewer members than the UNFCCC has and (2) aims to cooperate on one or more climate change-related activities, notably mitigation, adaptation, climate engineering or climate compensation (Hovi et al 2016). These climate clubs are found to be potentially relevant to break out of the consensusdeadlock of the UNFCCC. Also with respect to policy learning regarding to the Redd+ program, it could be relevant to explore if together with a group of likeminded countries such a climate club for this topic could be established. Such a club could focus on expanding the safeguards to for instance motivational crowding out and marginalization. Various UNFCCC member states opposed further guidance on the safeguards (e.g. Mexico and Ecuador), whereas other states (such as Norway and Bolivia) were in favour of it. Hence, it might also be relevant to explore the added value of a 'climate club' which would be willing to take the safeguards of PES programming to the next level. Such clubs could for instance have greater freedom to experiment with novel approaches to forest management that would be better equipped to deal with unintended consequences; for example so-called "landscape governance approaches" in which different sectors, actors and levels together deal with local and global challenges of their concern and thus potentially reduce marginalization and conflict (Ros-Tonen et al. 2018).

\section{Conclusion}

Let us return to the protestors with their 'No-REDD' signs and return to our three initial questions: (1) are there unintended effects; (2) are organizations dealing with them; (3) what is preventing organisations to deal (better) with them? We found a host of unintended effects of PES programmes and notice that mitigation strategies have only been partially successful in managing them. Does this mean that we support the protestors? On the basis of this research, we cannot reach such a conclusion, as we have only studied the unintended effects and not the intended effects. We have mapped only one side of the equation and so cannot determine if the costs outweigh the benefits. We can, however, provide clarity on the question of whether we think the costs are unnecessarily high and could be reduced.

We have concerns about the possibility that international organizations will overcome the institutional and ideological constraints to learning. Institutional constraints to learning (such as spending pressures) have been well documented in the past (e.g. Easterly 2001), and our research suggests that they might continue to plague international cooperation 
efforts. Also ideological constraints to learning-e.g. a strong belief that market- and monetary-driven solutions are the best solutions - cannot be overcome easily. Changes in these underlying core beliefs change slowly over time and are entwined with broader societal changes.

To end on a positive note, we are optimistic about the technical constraints identified. The constraints that prevent proper measurements (and mitigation) in the field of leakage and migration effects are mostly technical. If the organizations expand investments in this monitoring area, a clearer picture could emerge into the effective long-term effects of these PES programmes. With projected rises in funding for PES programmes, increased investments in enhancing measurement capacities in these (cross-boundary) unintended effects are warranted. If there are advocacy groups, be they donors, journalists or civil society activists that push for it, these technical boundaries might be overcome, especially with improved and more readily available high-tech monitoring solutions.

Open Access This article is licensed under a Creative Commons Attribution 4.0 International License, which permits use, sharing, adaptation, distribution and reproduction in any medium or format, as long as you give appropriate credit to the original author(s) and the source, provide a link to the Creative Commons licence, and indicate if changes were made. The images or other third party material in this article are included in the article's Creative Commons licence, unless indicated otherwise in a credit line to the material. If material is not included in the article's Creative Commons licence and your intended use is not permitted by statutory regulation or exceeds the permitted use, you will need to obtain permission directly from the copyright holder. To view a copy of this licence, visit http://creativecommons.org/licenses/by/4.0/.

\section{Appendix 1: Results literature review}

\begin{tabular}{|c|c|c|c|c|c|c|c|c|}
\hline & Author(s) & Year & Title & Link/info & Type & Effect(s) & $\begin{array}{l}\text { Level } \\
\text { (micro, } \\
\text { meso, } \\
\text { macro) }\end{array}$ & $\begin{array}{l}\text { Target } \\
\text { group/ } \\
\text { other } \\
\text { groups }\end{array}$ \\
\hline 1 & $\begin{array}{l}\text { Alpízar, F., } \\
\text { Nordén, } \\
\text { A., Pfaff, } \\
\text { A., and } \\
\text { Robalino, } \\
\text { J }\end{array}$ & 2017 & $\begin{array}{l}\text { Unintended } \\
\text { effects of } \\
\text { targeting an } \\
\text { environmental } \\
\text { rebate }\end{array}$ & $\begin{array}{l}\text { Environmental and } \\
\text { Resource Econom- } \\
\text { ics, 67(1), 181-202 }\end{array}$ & $\begin{array}{r}\text { Journal } \\
\text { article }\end{array}$ & $\begin{array}{l}\text { Motiva- } \\
\text { tion }\end{array}$ & Micro & $\begin{array}{l}\text { Other } \\
\text { groups }\end{array}$ \\
\hline 2 & $\begin{array}{l}\text { Agrawal, A., } \\
\text { Chhatre, } \\
\text { A., and } \\
\text { Gerber, } \\
\text { E. R }\end{array}$ & 2015 & $\begin{array}{l}\text { Motivational } \\
\text { crowding in } \\
\text { sustainable } \\
\text { development } \\
\text { interventions }\end{array}$ & $\begin{array}{l}\text { American Politi- } \\
\text { cal Science } \\
\text { Review, 109(3), } \\
470-487\end{array}$ & $\begin{array}{r}\text { Journal } \\
\text { article }\end{array}$ & $\begin{array}{l}\text { Motiva- } \\
\text { tion }\end{array}$ & Micro & $\begin{array}{l}\text { Target } \\
\text { group }\end{array}$ \\
\hline 3 & $\begin{array}{l}\text { Alix-Garcia, } \\
\text { J. M., } \\
\text { Shapiro, } \\
\text { E. N., } \\
\text { and Sims, } \\
\text { K. R }\end{array}$ & 2012 & $\begin{array}{l}\text { Forest conserva- } \\
\text { tion and slip- } \\
\text { page: Evidence } \\
\text { from Mexico's } \\
\text { national pay- } \\
\text { ments for eco- } \\
\text { system services } \\
\text { program }\end{array}$ & $\begin{array}{l}\text { Land Econom- } \\
\text { ics, 88(4), 613-638 }\end{array}$ & $\begin{array}{r}\text { Journal } \\
\text { article }\end{array}$ & Leakage & Meso & Both \\
\hline
\end{tabular}




\begin{tabular}{|c|c|c|c|c|c|c|c|c|}
\hline & Author(s) & Year & Title & Link/info & Type & Effect(s) & $\begin{array}{l}\text { Level } \\
\text { (micro, } \\
\text { meso, } \\
\text { macro) }\end{array}$ & $\begin{array}{l}\text { Target } \\
\text { group/ } \\
\text { other } \\
\text { groups }\end{array}$ \\
\hline 4 & $\begin{array}{l}\text { Alpízar, F., } \\
\text { Nordén, } \\
\text { A., Pfaff, } \\
\text { A., and } \\
\text { Robalino, } \\
\text { J }\end{array}$ & 2013 & $\begin{array}{l}\text { Effects of exclu- } \\
\text { sion from a } \\
\text { conservation } \\
\text { policy: negative } \\
\text { behavioral } \\
\text { spillovers from } \\
\text { targeted incen- } \\
\text { tives }\end{array}$ & $\begin{array}{l}\text { Duke Environmental } \\
\text { and Energy Eco- } \\
\text { nomics Working } \\
\text { Paper EE, 13-06 }\end{array}$ & $\begin{array}{c}\text { Working } \\
\text { paper }\end{array}$ & $\begin{array}{l}\text { Motiva- } \\
\text { tion }\end{array}$ & Meso & $\begin{array}{l}\text { Other } \\
\text { groups }\end{array}$ \\
\hline 5 & $\begin{array}{l}\text { Arriagada, } \\
\text { R. A., } \\
\text { Ferraro, } \\
\text { P. J., Sills, } \\
\text { E. O., Pat- } \\
\text { tanayak, } \\
\text { S. K., and } \\
\text { Cordero- } \\
\text { Sancho, S }\end{array}$ & 2012 & $\begin{array}{l}\text { Do payments for } \\
\text { environmental } \\
\text { services affect } \\
\text { forest cover? } \\
\text { A farm-level } \\
\text { evaluation from } \\
\text { Costa Rica }\end{array}$ & $\begin{array}{l}\text { Land Econom- } \\
\quad \text { ics, 88(2), 382-399 }\end{array}$ & $\begin{array}{r}\text { Journal } \\
\text { article }\end{array}$ & Leakage & Micro & $\begin{array}{l}\text { Target } \\
\text { group }\end{array}$ \\
\hline 6 & $\begin{array}{l}\text { Awono, A., } \\
\text { Somorin, } \\
\text { O. A., } \\
\text { Atyi, R. } \\
\text { E. A., and } \\
\text { Levang, P }\end{array}$ & 2014 & $\begin{array}{l}\text { Tenure and partic- } \\
\text { ipation in local } \\
\text { REDD+ pro- } \\
\text { jects: Insights } \\
\text { from southern } \\
\text { Cameroon }\end{array}$ & $\begin{array}{l}\text { Environmental } \\
\quad \text { Science and } \\
\text { Policy, 35, 76-86 }\end{array}$ & $\begin{array}{l}\text { Journal } \\
\text { article }\end{array}$ & $\begin{array}{l}\text { Indig- } \\
\text { enous } \\
\text { peo- } \\
\text { ples }\end{array}$ & Micro & $\begin{array}{l}\text { Target } \\
\text { group }\end{array}$ \\
\hline 7 & $\begin{array}{l}\text { Baylis, K., } \\
\text { Fullerton, } \\
\text { D., and } \\
\text { Shah, P }\end{array}$ & 2013 & $\begin{array}{l}\text { What drives forest } \\
\text { leakage }\end{array}$ & $\begin{array}{l}\text { Work. Pap., Dep. } \\
\text { Agric. Consum. } \\
\text { Econ., Univ. Ill., } \\
\text { Urbana-Cham- } \\
\text { paign }\end{array}$ & $\begin{array}{c}\text { Working } \\
\text { paper }\end{array}$ & Leakage & Micro & Both \\
\hline 8 & $\begin{array}{l}\text { Bayrak, } \\
\text { M., and } \\
\text { Marafa, L }\end{array}$ & 2017 & $\begin{array}{l}\text { Livelihood impli- } \\
\text { cations and per- } \\
\text { ceptions of large } \\
\text { scale invest- } \\
\text { ment in natural } \\
\text { resources for } \\
\text { conservation } \\
\text { and carbon } \\
\text { sequestration: } \\
\text { Empirical } \\
\text { evidence from } \\
\text { REDD+ in } \\
\text { Vietnam }\end{array}$ & $\begin{array}{l}\text { Sustainability, 9(10), } \\
\quad 1802\end{array}$ & $\begin{array}{r}\text { Journal } \\
\text { article }\end{array}$ & $\begin{array}{l}\text { Margin- } \\
\text { aliza- } \\
\text { tion }\end{array}$ & Macro & Both \\
\hline 9 & $\begin{array}{l}\text { Bétrisey, F., } \\
\text { Mager, } \\
\text { C., and } \\
\text { Rist, S }\end{array}$ & 2016 & $\begin{array}{l}\text { Local views } \\
\text { and structural } \\
\text { determinants } \\
\text { of poverty alle- } \\
\text { viation through } \\
\text { payments for } \\
\text { environmental } \\
\text { services: Boliv- } \\
\text { ian insights }\end{array}$ & $\begin{array}{l}\text { World Development } \\
\text { Perspectives, } 1 \text {, } \\
\text { 6-11 }\end{array}$ & $\begin{array}{r}\text { Journal } \\
\text { article }\end{array}$ & $\begin{array}{l}\text { Margin- } \\
\text { aliza- } \\
\text { tion }\end{array}$ & Micro & $\begin{array}{l}\text { Target } \\
\text { group }\end{array}$ \\
\hline
\end{tabular}




\begin{tabular}{|c|c|c|c|c|c|c|c|c|}
\hline & Author(s) & Year & Title & Link/info & Type & Effect(s) & $\begin{array}{l}\text { Level } \\
\text { (micro, } \\
\text { meso, } \\
\text { macro) }\end{array}$ & $\begin{array}{l}\text { Target } \\
\text { group/ } \\
\text { other } \\
\text { groups }\end{array}$ \\
\hline 10 & $\begin{array}{l}\text { Bremer, L. } \\
\text { L., Farley, } \\
\text { K. A., and } \\
\text { Lopez- } \\
\text { Carr, D }\end{array}$ & 2014 & $\begin{array}{l}\text { What factors } \\
\text { influence } \\
\text { participation } \\
\text { in payment for } \\
\text { ecosystem ser- } \\
\text { vices programs? } \\
\text { An evaluation } \\
\text { of Ecuador's } \\
\text { SocioPáramo } \\
\text { program }\end{array}$ & $\begin{array}{l}\text { Land Use Policy, 36, } \\
\text { 122-133 }\end{array}$ & $\begin{array}{l}\text { Journal } \\
\text { article }\end{array}$ & $\begin{array}{l}\text { Margin- } \\
\text { aliza- } \\
\text { tion }\end{array}$ & Micro & Both \\
\hline 11 & Clifton, J & 2013 & $\begin{array}{l}\text { Compensation, } \\
\text { conservation } \\
\text { and communi- } \\
\text { ties: an analysis } \\
\text { of direct pay- } \\
\text { ments initiatives } \\
\text { within an Indo- } \\
\text { nesian marine } \\
\text { protected area }\end{array}$ & $\begin{array}{l}\text { Environmental con- } \\
\text { servation, } 40(3) \text {, } \\
287-295\end{array}$ & $\begin{array}{l}\text { Journal } \\
\text { article }\end{array}$ & $\begin{array}{l}\text { Margin- } \\
\text { aliza- } \\
\text { tion }\end{array}$ & Meso & Both \\
\hline 12 & $\begin{array}{l}\text { Corbera, E., } \\
\text { Brown, } \\
\text { K., and } \\
\text { Adger, } \\
\text { W. N }\end{array}$ & 2007 & $\begin{array}{l}\text { The equity and } \\
\text { legitimacy of } \\
\text { markets for eco- } \\
\text { system services }\end{array}$ & $\begin{array}{l}\text { Development and } \\
\text { change, 38(4), } \\
587-613\end{array}$ & $\begin{array}{l}\text { Journal } \\
\text { article }\end{array}$ & $\begin{array}{l}\text { Margin- } \\
\text { aliza- } \\
\text { tion }\end{array}$ & Micro & $\begin{array}{l}\text { Target } \\
\text { group }\end{array}$ \\
\hline 13 & $\begin{array}{l}\text { Corbera, E., } \\
\text { Kosoy, N., } \\
\text { and Tuna, } \\
\text { M. M }\end{array}$ & 2007 & $\begin{array}{l}\text { Equity implica- } \\
\text { tions of market- } \\
\text { ing ecosystem } \\
\text { services in } \\
\text { protected areas } \\
\text { and rural com- } \\
\text { munities: Case } \\
\text { studies from } \\
\text { Meso-America }\end{array}$ & $\begin{array}{l}\text { Global Environmen- } \\
\text { tal Change, 17(3- } \\
\text { 4), 365-380 }\end{array}$ & $\begin{array}{l}\text { Journal } \\
\text { article }\end{array}$ & Conflict & Meso & $\begin{array}{l}\text { Target } \\
\text { group }\end{array}$ \\
\hline 14 & $\begin{array}{l}\text { Couto } \\
\text { Pereira, } \\
\text { S. N }\end{array}$ & 2010 & $\begin{array}{l}\text { Payment for } \\
\text { environmental } \\
\text { services in the } \\
\text { Amazon forest: } \\
\text { how can con- } \\
\text { servation and } \\
\text { development be } \\
\text { reconciled? }\end{array}$ & $\begin{array}{l}\text { The Journal of } \\
\text { Environment } \\
\text { and Develop- } \\
\text { ment, 19(2), } \\
\text { 171-190 }\end{array}$ & $\begin{array}{l}\text { Journal } \\
\text { article }\end{array}$ & $\begin{array}{c}\text { Indig- } \\
\text { enous } \\
\text { Peo- } \\
\text { ples }\end{array}$ & Meso & $\begin{array}{l}\text { Target } \\
\text { group }\end{array}$ \\
\hline 15 & $\begin{array}{l}\text { de Fran- } \\
\text { cisco, J., } \\
\text { and Boe- } \\
\text { lens, R }\end{array}$ & 2014 & $\begin{array}{l}\text { Payment for } \\
\text { environmental } \\
\text { services and } \\
\text { power in the } \\
\text { Chamachán } \\
\text { watershed, } \\
\text { Ecuador }\end{array}$ & $\begin{array}{l}\text { Human Organi- } \\
\text { zation, 73(4), } \\
351-362\end{array}$ & $\begin{array}{l}\text { Journal } \\
\text { article }\end{array}$ & $\begin{array}{l}\text { Indig- } \\
\text { enous } \\
\text { peo- } \\
\text { ples }\end{array}$ & Micro & $\begin{array}{l}\text { Target } \\
\text { group }\end{array}$ \\
\hline 16 & $\begin{array}{l}\text { Delacote, } \\
\text { P., and } \\
\text { Angelsen, } \\
\text { A }\end{array}$ & 2015 & $\begin{array}{l}\text { Reducing defor- } \\
\text { estation and } \\
\text { forest degrada- } \\
\text { tion: leakage or } \\
\text { synergy? }\end{array}$ & $\begin{array}{l}\text { Land Econom- } \\
\quad \text { ics, } 91(3), 501-515\end{array}$ & $\begin{array}{l}\text { Journal } \\
\text { Article }\end{array}$ & Leakage & Micro & Both \\
\hline
\end{tabular}




\begin{tabular}{|c|c|c|c|c|c|c|c|c|}
\hline & Author(s) & Year & Title & Link/info & Type & Effect(s) & $\begin{array}{l}\text { Level } \\
\text { (micro, } \\
\text { meso, } \\
\text { macro) }\end{array}$ & $\begin{array}{l}\text { Target } \\
\text { group/ } \\
\text { other } \\
\text { groups }\end{array}$ \\
\hline 17 & $\begin{array}{l}\text { Démurger, } \\
\text { S., and } \\
\text { Wan, H }\end{array}$ & 2012 & $\begin{array}{l}\text { Payments for } \\
\text { ecological } \\
\text { restoration and } \\
\text { internal migra- } \\
\text { tion in China: } \\
\text { the sloping } \\
\text { land conver- } \\
\text { sion program in } \\
\text { Ningxia }\end{array}$ & $\begin{array}{l}\text { IZA Journal of } \\
\quad \text { Migration, 1(1), } 10\end{array}$ & $\begin{array}{l}\text { Journal } \\
\text { Article }\end{array}$ & $\begin{array}{l}\text { Migra- } \\
\text { tion }\end{array}$ & Meso & $\begin{array}{l}\text { Target } \\
\text { group }\end{array}$ \\
\hline 18 & Erazo, J & 2013 & $\begin{array}{l}\text { REDD: Develop- } \\
\text { ment Oppor- } \\
\text { tunity or Neo- } \\
\text { liberal Threat? } \\
\text { Indigenous } \\
\text { Organizations } \\
\text { Take Opposing } \\
\text { Views }\end{array}$ & $\begin{array}{l}\text { NACLA Report } \\
\text { on the Americas } \\
46: 55-60\end{array}$ & $\begin{array}{l}\text { Journal } \\
\text { article }\end{array}$ & $\begin{array}{l}\text { Indig- } \\
\text { enous } \\
\text { Peo- } \\
\text { ples }\end{array}$ & Micro & $\begin{array}{l}\text { Target } \\
\text { group }\end{array}$ \\
\hline 19 & Fisher, J & 2012 & $\begin{array}{l}\text { No pay, no care? } \\
\text { A case study } \\
\text { exploring } \\
\text { motivations for } \\
\text { participation } \\
\text { in payments } \\
\text { for ecosystem } \\
\text { services in } \\
\text { Uganda }\end{array}$ & Oryx, 46(1), 45-54 & $\begin{array}{l}\text { Journal } \\
\text { article }\end{array}$ & $\begin{array}{l}\text { Motiva- } \\
\text { tion }\end{array}$ & Micro & $\begin{array}{l}\text { Target } \\
\text { group }\end{array}$ \\
\hline 20 & $\begin{array}{l}\text { García- } \\
\text { Amado, L. } \\
\text { R., Pérez, } \\
\text { M. R., and } \\
\text { García, } \\
\text { S. B }\end{array}$ & 2013 & $\begin{array}{l}\text { Motivation for } \\
\text { conservation: } \\
\text { assessing } \\
\text { integrated con- } \\
\text { servation and } \\
\text { development } \\
\text { projects and } \\
\text { payments for } \\
\text { environmental } \\
\text { services in La } \\
\text { Sepultura Bio- } \\
\text { sphere Reserve, } \\
\text { Chiapas, } \\
\text { Mexico }\end{array}$ & $\begin{array}{l}\text { Ecological Econom- } \\
\text { ics, } 89,92-100\end{array}$ & $\begin{array}{l}\text { Journal } \\
\text { article }\end{array}$ & $\begin{array}{l}\text { Motiva- } \\
\text { tion }\end{array}$ & Micro & $\begin{array}{l}\text { Target } \\
\text { group }\end{array}$ \\
\hline 21 & Gauthier, M & 2018 & $\begin{array}{l}\text { Mai-Ndombe: } \\
\text { Will the } \\
\text { REDD+ labora- } \\
\text { tory benefit } \\
\text { indigenous peo- } \\
\text { ples and local } \\
\text { communities }\end{array}$ & $\begin{array}{l}\text { Rights and } \\
\text { Resources Initia- } \\
\text { tive: https://right } \\
\text { sandresources. } \\
\text { org/wp-content/ } \\
\text { uploads/2018/03/ } \\
\text { EN_Mai-Ndomb } \\
\text { e-Report_RRI_- } \\
\text { Mar-2018.pdf }\end{array}$ & Paper & $\begin{array}{l}\text { Indig- } \\
\text { enous } \\
\text { Peo- } \\
\text { ples }\end{array}$ & Meso & Both \\
\hline
\end{tabular}




\begin{tabular}{|c|c|c|c|c|c|c|c|c|}
\hline & Author(s) & Year & Title & Link/info & Type & Effect(s) & $\begin{array}{l}\text { Level } \\
\text { (micro, } \\
\text { meso, } \\
\text { macro) }\end{array}$ & $\begin{array}{l}\text { Target } \\
\text { group/ } \\
\text { other } \\
\text { groups }\end{array}$ \\
\hline 22 & $\begin{array}{l}\text { Gebara, } \\
\text { M., and } \\
\text { Agrawal, } \\
\text { A }\end{array}$ & 2017 & $\begin{array}{l}\text { Beyond rewards } \\
\text { and punish- } \\
\text { ments in the } \\
\text { Brazilian } \\
\text { Amazon: Practi- } \\
\text { cal implications } \\
\text { of the REDD+ } \\
\text { discourse }\end{array}$ & Forests, 8(3), 66 & $\begin{array}{r}\text { Journal } \\
\text { article }\end{array}$ & $\begin{array}{l}\text { Motiva- } \\
\text { tion }\end{array}$ & Micro & $\begin{array}{l}\text { Target } \\
\text { group }\end{array}$ \\
\hline 23 & $\begin{array}{l}\text { Gong, Y., } \\
\text { Bull, G., } \\
\text { and Bay- } \\
\text { lis, K }\end{array}$ & 2010 & $\begin{array}{l}\text { Participation in } \\
\text { the world's first } \\
\text { clean develop- } \\
\text { ment mecha- } \\
\text { nism forest pro- } \\
\text { ject: the role of } \\
\text { property rights, } \\
\text { social capital } \\
\text { and contractual } \\
\text { rules }\end{array}$ & $\begin{array}{l}\text { Ecological Eco- } \\
\text { nomics, 69(6), } \\
1292-1302\end{array}$ & $\begin{array}{l}\text { Journal } \\
\text { article }\end{array}$ & Conflict & Micro & $\begin{array}{l}\text { Target } \\
\text { group }\end{array}$ \\
\hline 24 & $\begin{array}{l}\text { Hazlewood, } \\
\text { J. A }\end{array}$ & 2010 & $\begin{array}{l}\text { Geographies of } \\
\mathrm{CO}_{2} \text { lonialism } \\
\text { and hope in the } \\
\text { NorthwestPa- } \\
\text { cific Frontier } \\
\text { Territory-region } \\
\text { of Ecuador }\end{array}$ & $\begin{array}{l}\text { University of Ken- } \\
\text { tucky: }\end{array}$ & $\begin{array}{l}\text { Doctoral } \\
\text { Dis- } \\
\text { sertation } \\
\text { (unpub- } \\
\text { lished) }\end{array}$ & $\begin{array}{l}\text { Margin- } \\
\text { aliza- } \\
\text { tion }\end{array}$ & Micro & $\begin{array}{l}\text { Target } \\
\text { group }\end{array}$ \\
\hline 25 & $\begin{array}{l}\text { Ibarra, J. } \\
\text { T., Bar- } \\
\text { reau, A., } \\
\text { Campo, C. } \\
\text { D., Cama- } \\
\text { cho, C. I., } \\
\text { Martin, } \\
\text { G. J., and } \\
\text { McCand- } \\
\text { less, S. R }\end{array}$ & 2011 & $\begin{array}{l}\text { When formal and } \\
\text { market-based } \\
\text { conservation } \\
\text { mechanisms } \\
\text { disrupt food } \\
\text { sovereignty: } \\
\text { impacts of } \\
\text { community } \\
\text { conservation } \\
\text { and payments } \\
\text { for environmen- } \\
\text { tal services on } \\
\text { an indigenous } \\
\text { community of } \\
\text { Oaxaca, Mexico }\end{array}$ & $\begin{array}{l}\text { International } \\
\quad \text { Forestry } \\
\text { Review, 13(3), } \\
\text { 318-337 }\end{array}$ & $\begin{array}{l}\text { Journal } \\
\text { article }\end{array}$ & $\begin{array}{l}\text { Indig- } \\
\text { enous } \\
\text { Peo- } \\
\text { ples }\end{array}$ & Micro & $\begin{array}{l}\text { Target } \\
\text { group }\end{array}$ \\
\hline
\end{tabular}




\begin{tabular}{|c|c|c|c|c|c|c|c|c|}
\hline & Author(s) & Year & Title & Link/info & Type & Effect(s) & $\begin{array}{l}\text { Level } \\
\text { (micro, } \\
\text { meso, } \\
\text { macro) }\end{array}$ & $\begin{array}{l}\text { Target } \\
\text { group/ } \\
\text { other } \\
\text { groups }\end{array}$ \\
\hline 26 & $\begin{array}{l}\text { Ibarra, J. } \\
\text { T., Bar- } \\
\text { reau, A., } \\
\text { Campo, C. } \\
\text { D., Cama- } \\
\text { cho, C. I., } \\
\text { Martin, } \\
\text { G. J., and } \\
\text { McCand- } \\
\text { less, S. R }\end{array}$ & 2011 & $\begin{array}{l}\text { When formal and } \\
\text { market-based } \\
\text { conservation } \\
\text { mechanisms } \\
\text { disrupt food } \\
\text { sovereignty: } \\
\text { impacts of } \\
\text { community } \\
\text { conservation } \\
\text { and payments } \\
\text { for environmen- } \\
\text { tal services on } \\
\text { an indigenous } \\
\text { community of } \\
\text { Oaxaca, Mexico }\end{array}$ & $\begin{array}{l}\text { International } \\
\quad \text { Forestry } \\
\text { Review, 13(3), } \\
\text { 318-337 }\end{array}$ & $\begin{array}{l}\text { Journal } \\
\text { article }\end{array}$ & $\begin{array}{l}\text { Migra- } \\
\text { tion, } \\
\text { Mar- } \\
\text { ginali- } \\
\text { zation }\end{array}$ & Meso & $\begin{array}{l}\text { Target } \\
\text { group }\end{array}$ \\
\hline 27 & Isyaku, U & 2017 & $\begin{array}{l}\text { Beyond policy } \\
\text { design: REDD+ } \\
\text { implementation } \\
\text { and institutional } \\
\text { complexities of } \\
\text { environmental } \\
\text { governance in } \\
\text { Cross River } \\
\text { state, Nigeria }\end{array}$ & $\begin{array}{l}\text { Doctoral disserta- } \\
\text { tion, University of } \\
\text { Leicester, Depart- } \\
\text { ment of Geography }\end{array}$ & $\begin{array}{l}\text { Doctoral } \\
\text { Disser- } \\
\text { tation }\end{array}$ & $\begin{array}{l}\text { Motiva- } \\
\text { tion }\end{array}$ & Meso & $\begin{array}{l}\text { Target } \\
\text { group }\end{array}$ \\
\hline 28 & $\begin{array}{c}\text { Jack, B. K., } \\
\text { and San- } \\
\text { tos, E. C }\end{array}$ & 2017 & $\begin{array}{l}\text { The leakage } \\
\text { and livelihood } \\
\text { impacts of PES } \\
\text { contracts: A } \\
\text { targeting experi- } \\
\text { ment in Malawi }\end{array}$ & $\begin{array}{l}\text { Land Use Policy, 63, } \\
\quad 645-658\end{array}$ & $\begin{array}{l}\text { Journal } \\
\text { Article }\end{array}$ & Leakage & Micro & $\begin{array}{l}\text { Target } \\
\text { group }\end{array}$ \\
\hline 29 & $\begin{array}{l}\text { Kerr, J., } \\
\text { Vardhan, } \\
\text { M., and } \\
\text { Jindal, R }\end{array}$ & 2012 & $\begin{array}{l}\text { Prosocial } \\
\text { behavior and } \\
\text { incentives: evi- } \\
\text { dence from field } \\
\text { experiments in } \\
\text { rural Mexico } \\
\text { and Tanzania }\end{array}$ & $\begin{array}{l}\text { Ecological Econom- } \\
\text { ics, 73, 220-227 }\end{array}$ & $\begin{array}{l}\text { Journal } \\
\text { article }\end{array}$ & $\begin{array}{l}\text { Motiva- } \\
\text { tion }\end{array}$ & Meso & $\begin{array}{l}\text { Target } \\
\text { group }\end{array}$ \\
\hline 30 & $\begin{array}{l}\text { Kerr, J., } \\
\text { Vardhan, } \\
\text { M., and } \\
\text { Jindal, R }\end{array}$ & 2012 & $\begin{array}{l}\text { Prosocial } \\
\text { behavior and } \\
\text { incentives: evi- } \\
\text { dence from field } \\
\text { experiments in } \\
\text { rural Mexico } \\
\text { and Tanzania }\end{array}$ & $\begin{array}{l}\text { Ecological Econom- } \\
\text { ics, 73, 220-227 }\end{array}$ & $\begin{array}{l}\text { Journal } \\
\text { Article }\end{array}$ & $\begin{array}{l}\text { Motiva- } \\
\text { tion }\end{array}$ & Meso & $\begin{array}{l}\text { Target } \\
\text { group }\end{array}$ \\
\hline 31 & $\begin{array}{l}\text { Kolinjivadi, } \\
\text { V., Charré, } \\
\text { S., Ada- } \\
\text { mowski, } \\
\text { J., and } \\
\text { Kosoy, N }\end{array}$ & 2019 & $\begin{array}{l}\text { Economic } \\
\text { experiments for } \\
\text { collective action } \\
\text { in the Kyrgyz } \\
\text { Republic: } \\
\text { lessons for pay- } \\
\text { ments for eco- } \\
\text { system services } \\
\text { (PES) }\end{array}$ & $\begin{array}{c}\text { Ecological Econom- } \\
\text { ics, 156, 489-498 }\end{array}$ & $\begin{array}{l}\text { Journal } \\
\text { Article }\end{array}$ & $\begin{array}{l}\text { Motiva- } \\
\text { tion }\end{array}$ & Meso & $\begin{array}{l}\text { Target } \\
\text { group }\end{array}$ \\
\hline
\end{tabular}




\begin{tabular}{|c|c|c|c|c|c|c|c|c|}
\hline & Author(s) & Year & Title & Link/info & Type & Effect(s) & $\begin{array}{l}\text { Level } \\
\text { (micro, } \\
\text { meso, } \\
\text { macro) }\end{array}$ & $\begin{array}{l}\text { Target } \\
\text { group/ } \\
\text { other } \\
\text { groups }\end{array}$ \\
\hline 32 & $\begin{array}{l}\text { Krause, T., } \\
\text { Collen, } \\
\text { W., and } \\
\text { Nicholas, } \\
\text { K }\end{array}$ & 2013 & $\begin{array}{l}\text { Evaluating } \\
\text { safeguards in } \\
\text { a conserva- } \\
\text { tion incentive } \\
\text { program: } \\
\text { participation, } \\
\text { consent, and } \\
\text { benefit sharing } \\
\text { in indigenous } \\
\text { communities of } \\
\text { the Ecuadorian } \\
\text { Amazon }\end{array}$ & $\begin{array}{l}\text { Ecology and Soci- } \\
\text { ety, 18(4) }\end{array}$ & $\begin{array}{c}\text { Journal } \\
\text { article }\end{array}$ & $\begin{array}{l}\text { Indig- } \\
\text { enous } \\
\text { Peo- } \\
\text { ples/ } \\
\text { Con- } \\
\text { flict }\end{array}$ & Meso & $\begin{array}{l}\text { Target } \\
\text { group }\end{array}$ \\
\hline 33 & $\begin{array}{l}\text { Lansing, } \\
\text { D. M }\end{array}$ & 2014 & $\begin{array}{l}\text { Unequal access } \\
\text { to payments for } \\
\text { ecosystem ser- } \\
\text { vices: The case } \\
\text { of Costa Rica }\end{array}$ & $\begin{array}{l}\text { Development and } \\
\text { Change, } 45(6) \text {, } \\
\text { 1310-1331 }\end{array}$ & $\begin{array}{c}\text { Journal } \\
\text { article }\end{array}$ & $\begin{array}{l}\text { Margin- } \\
\text { aliza- } \\
\text { tion }\end{array}$ & Micro & Both \\
\hline 34 & $\begin{array}{l}\text { Leggett, } \\
\text { M., and } \\
\text { Lovell, H }\end{array}$ & 2012 & $\begin{array}{l}\text { Community } \\
\text { perceptions } \\
\text { of REDD+: a } \\
\text { case study from } \\
\text { Papua New } \\
\text { Guinea }\end{array}$ & $\begin{array}{c}\text { Climate Pol- } \\
\text { icy, 12(1), } \\
115-134\end{array}$ & $\begin{array}{c}\text { Journal } \\
\text { article }\end{array}$ & $\begin{array}{l}\text { Indig- } \\
\text { enous } \\
\text { Peo- } \\
\text { ples }\end{array}$ & Micro & $\begin{array}{l}\text { Target } \\
\text { group }\end{array}$ \\
\hline 35 & $\begin{array}{l}\text { Llanos, } \\
\text { R.E. and } \\
\text { Feather, C }\end{array}$ & 2011 & $\begin{array}{l}\text { The reality of } \\
\text { REDD+ in } \\
\text { Peru: Between } \\
\text { theory and } \\
\text { practice }\end{array}$ & $\begin{array}{l}\text { Asociación Interét- } \\
\text { nica de Desarrollo } \\
\text { de la Selva Peruana } \\
\text { and Forest Peoples } \\
\text { Programme: https } \\
\text { ://www.forestpeop } \\
\text { les.org/sites/fpp/ } \\
\text { files/publicatio } \\
\text { n/2011/11/reali } \\
\text { ty-redd-peru-betwe } \\
\text { en-theory-and- } \\
\text { practice-novem } \\
\text { ber-2011.pdf }\end{array}$ & Paper & $\begin{array}{l}\text { Indig- } \\
\text { enous } \\
\text { Peo- } \\
\text { ples }\end{array}$ & Micro & $\begin{array}{l}\text { Target } \\
\text { group }\end{array}$ \\
\hline 36 & $\begin{array}{l}\text { Luo, J., LI, } \\
\text { C., Huang, } \\
\text { J., and } \\
\text { Wu, Y }\end{array}$ & 2007 & $\begin{array}{l}\text { The analysis } \\
\text { of ecological } \\
\text { footprint of } \\
\text { Hubei Province } \\
\text { in } 2004\end{array}$ & $\begin{array}{l}\text { Journal of Huazhong } \\
\text { Normal University } \\
\text { (Natural Sciences), } \\
\text { (2), } 38\end{array}$ & $\begin{array}{l}\text { Journal } \\
\text { article }\end{array}$ & $\begin{array}{l}\text { Migra- } \\
\text { tion }\end{array}$ & Meso & Both \\
\hline 37 & $\begin{array}{l}\text { Mahanty, S., } \\
\text { Dressler, } \\
\text { W., Milne, } \\
\text { S., and } \\
\text { Filer, C }\end{array}$ & 2013 & $\begin{array}{l}\text { Unravelling prop- } \\
\text { erty relations } \\
\text { around forest } \\
\text { carbon }\end{array}$ & $\begin{array}{l}\text { Singapore Jour- } \\
\text { nal of Tropical } \\
\text { Geography, 34(2), } \\
\text { 188-205 }\end{array}$ & $\begin{array}{l}\text { Journal } \\
\text { Article }\end{array}$ & Conflict & Meso & $\begin{array}{l}\text { Other } \\
\text { groups }\end{array}$ \\
\hline
\end{tabular}




\begin{tabular}{|c|c|c|c|c|c|c|c|c|}
\hline & Author(s) & Year & Title & Link/info & Type & Effect(s) & $\begin{array}{l}\text { Level } \\
\text { (micro, } \\
\text { meso, } \\
\text { macro) }\end{array}$ & $\begin{array}{l}\text { Target } \\
\text { group/ } \\
\text { other } \\
\text { groups }\end{array}$ \\
\hline 38 & $\begin{array}{l}\text { Martin, A., } \\
\text { Gross- } \\
\text { Camp, N., } \\
\text { Kebede, } \\
\text { B., } \\
\text { McGuire, } \\
\text { S., and } \\
\text { Munyaru- } \\
\text { kaza, J }\end{array}$ & 2014 & $\begin{array}{l}\text { Whose environ- } \\
\text { mental justice? } \\
\text { Exploring local } \\
\text { and global } \\
\text { perspectives } \\
\text { in a payments } \\
\text { for ecosystem } \\
\text { services scheme } \\
\text { in Rwanda }\end{array}$ & $\begin{array}{l}\text { Geoforum, 54, } \\
167-177\end{array}$ & $\begin{array}{r}\text { Journal } \\
\text { article }\end{array}$ & $\begin{array}{c}\text { Indig- } \\
\text { enous } \\
\text { Peo- } \\
\text { ples }\end{array}$ & Micro & $\begin{array}{l}\text { Target } \\
\text { group }\end{array}$ \\
\hline 39 & $\begin{array}{l}\text { Moros, L., } \\
\text { Vélez, M. } \\
\text { A., and } \\
\text { Corbera, E }\end{array}$ & 2019 & $\begin{array}{l}\text { Payments for eco- } \\
\text { system services } \\
\text { and motiva- } \\
\text { tional crowding } \\
\text { in Colombia's } \\
\text { Amazon Pied- } \\
\text { mont }\end{array}$ & $\begin{array}{l}\text { Ecological econom- } \\
\text { ics, } 156,468-488\end{array}$ & $\begin{array}{c}\text { Journal } \\
\text { article }\end{array}$ & $\begin{array}{l}\text { Motiva- } \\
\text { tion }\end{array}$ & Micro & $\begin{array}{l}\text { Target } \\
\text { group }\end{array}$ \\
\hline 40 & Morse, W. C & 2007 & $\begin{array}{l}\text { Payments for } \\
\text { environmental } \\
\text { services in } \\
\text { Costa Rica: } \\
\text { conservation } \\
\text { and production } \\
\text { decisions within } \\
\text { the San Juan-La } \\
\text { Selva Biological } \\
\text { Corridor }\end{array}$ & $\begin{array}{l}\text { University of Idaho. } \\
\text { https://www. } \\
\text { sidalc.net/repdo } \\
\text { c/A1670I/A1670 } \\
\text { I.pdf }\end{array}$ & $\begin{array}{l}\text { Doctoral } \\
\text { Disser- } \\
\text { tation }\end{array}$ & $\begin{array}{l}\text { Margin- } \\
\text { aliza- } \\
\text { tion }\end{array}$ & Meso & Both \\
\hline 41 & Mwangi, O & 2007 & $\begin{array}{l}\text { Hydropolitics, } \\
\text { ecocide and } \\
\text { human security } \\
\text { in Lesotho: a } \\
\text { case study of } \\
\text { the Lesotho } \\
\text { Highlands } \\
\text { Water project }\end{array}$ & $\begin{array}{l}\text { Journal of Southern } \\
\text { African Stud- } \\
\text { ies, 33(1), 3-17 }\end{array}$ & $\begin{array}{l}\text { Journal } \\
\text { article }\end{array}$ & $\begin{array}{l}\text { Migra- } \\
\text { tion, } \\
\text { Mar- } \\
\text { ginali- } \\
\text { zation }\end{array}$ & Meso & $\begin{array}{l}\text { Target } \\
\text { group }\end{array}$ \\
\hline 42 & $\begin{array}{l}\text { Narloch, U., } \\
\text { Pascual, } \\
\text { U., and } \\
\text { Drucker, } \\
\text { A. G }\end{array}$ & 2012 & $\begin{array}{l}\text { Collective action } \\
\text { dynamics } \\
\text { under external } \\
\text { rewards: experi- } \\
\text { mental insights } \\
\text { from Andean } \\
\text { farming com- } \\
\text { munities }\end{array}$ & $\begin{array}{l}\text { World Develop- } \\
\text { ment, 40(10), } \\
\text { 2096-2107 }\end{array}$ & $\begin{array}{l}\text { Journal } \\
\text { article }\end{array}$ & $\begin{array}{l}\text { Motiva- } \\
\text { tion }\end{array}$ & Micro & $\begin{array}{l}\text { Target } \\
\text { group }\end{array}$ \\
\hline 43 & Nordén, A & 2013 & $\begin{array}{l}\text { Essays on Behav- } \\
\text { ioral Economics } \\
\text { and Policies } \\
\text { for Provision } \\
\text { of Ecosystem } \\
\text { Services }\end{array}$ & $\begin{array}{l}\text { University of } \\
\text { Gothenburg: } \\
\text { https://gupea } \\
\text {.ub.gu.se/bitst } \\
\text { ream/2077/32759 } \\
\text { /1/gupea } \\
\text { _2077_32759 } \\
\text { _1.pdf }\end{array}$ & $\begin{array}{l}\text { Doctoral } \\
\text { Disser- } \\
\text { tation }\end{array}$ & $\begin{array}{l}\text { Motiva- } \\
\text { tion }\end{array}$ & Micro & $\begin{array}{l}\text { Other } \\
\text { groups }\end{array}$ \\
\hline
\end{tabular}




\begin{tabular}{|c|c|c|c|c|c|c|c|c|}
\hline & Author(s) & Year & Title & Link/info & Type & Effect(s) & $\begin{array}{l}\text { Level } \\
\text { (micro, } \\
\text { meso, } \\
\text { macro) }\end{array}$ & $\begin{array}{l}\text { Target } \\
\text { group/ } \\
\text { other } \\
\text { groups }\end{array}$ \\
\hline 44 & $\begin{array}{l}\text { Oestreicher, } \\
\text { J. S., } \\
\text { Benes- } \\
\text { saiah, K., } \\
\text { Ruiz-Jaen, } \\
\text { M. C., } \\
\text { Sloan, S., } \\
\text { Turner, } \\
\text { K., Pel- } \\
\text { letier, J., } \\
\text {... and } \\
\text { Potvin, C }\end{array}$ & 2009 & $\begin{array}{l}\text { Avoiding } \\
\text { deforestation } \\
\text { in Panamanian } \\
\text { protected areas: } \\
\text { an analysis } \\
\text { of protection } \\
\text { effectiveness } \\
\text { and implications } \\
\text { for reducing } \\
\text { emissions from } \\
\text { deforestation } \\
\text { and forest deg- } \\
\text { radation }\end{array}$ & $\begin{array}{l}\text { Global Environmen- } \\
\text { tal Change, 19(2), } \\
\text { 279-291 }\end{array}$ & $\begin{array}{l}\text { Journal } \\
\text { article }\end{array}$ & Leakage & Micro & $\begin{array}{l}\text { Target } \\
\text { group }\end{array}$ \\
\hline 45 & $\begin{array}{l}\text { Pokorny, B., } \\
\text { Scholz, } \\
\text { I., and De } \\
\text { Jong, W }\end{array}$ & 2013 & $\begin{array}{l}\text { REDD+ for the } \\
\text { poor or the poor } \\
\text { for REDD+? } \\
\text { About the } \\
\text { limitations of } \\
\text { environmental } \\
\text { policies in the } \\
\text { Amazon and } \\
\text { the potential } \\
\text { of achieving } \\
\text { environmental } \\
\text { goals through } \\
\text { pro-poor poli- } \\
\text { cies }\end{array}$ & $\begin{array}{l}\text { Ecology and Soci- } \\
\text { ety, 18(2) }\end{array}$ & $\begin{array}{l}\text { Journal } \\
\text { article }\end{array}$ & $\begin{array}{l}\text { Indig- } \\
\text { enous } \\
\text { Peo- } \\
\text { ples/ } \\
\text { mar- } \\
\text { ginali- } \\
\text { zation }\end{array}$ & Meso & $\begin{array}{l}\text { Target } \\
\text { group }\end{array}$ \\
\hline 46 & Reed, P & 2011 & $\begin{array}{l}\text { REDD+ and the } \\
\text { indigenous } \\
\text { question: a case } \\
\text { study from } \\
\text { Ecuador }\end{array}$ & $\begin{array}{l}\text { Forests, 2(2), } \\
525-549\end{array}$ & $\begin{array}{l}\text { Journal } \\
\text { article }\end{array}$ & $\begin{array}{l}\text { Indig- } \\
\text { enous } \\
\text { Peo- } \\
\text { ples }\end{array}$ & Micro & $\begin{array}{l}\text { Target } \\
\text { group }\end{array}$ \\
\hline 47 & $\begin{array}{l}\text { Rodríguez } \\
\text { de Fran- } \\
\text { cisco, J. } \\
\text { C., Budds, } \\
\text { J., and } \\
\text { Boelens, } \\
\text { R }\end{array}$ & 2013 & $\begin{array}{l}\text { Payment for } \\
\text { environmen- } \\
\text { tal services } \\
\text { and unequal } \\
\text { resource control } \\
\text { in Pimampiro, } \\
\text { Ecuador }\end{array}$ & $\begin{array}{l}\text { Society and Natural } \\
\text { Resources, 26(10), } \\
1217-1233\end{array}$ & $\begin{array}{l}\text { Journal } \\
\text { article }\end{array}$ & $\begin{array}{l}\text { Margin- } \\
\text { aliza- } \\
\text { tion }\end{array}$ & Micro & $\begin{array}{l}\text { Target } \\
\text { group }\end{array}$ \\
\hline 48 & $\begin{array}{l}\text { Saito- } \\
\text { Jensen, } \\
\text { M., Rutt, } \\
\text { R. L., and } \\
\text { Chhetri, } \\
\text { B. B. K }\end{array}$ & 2014 & $\begin{array}{l}\text { Social and } \\
\text { environmen- } \\
\text { tal tensions: } \\
\text { affirmative } \\
\text { measures under } \\
\text { REDD+ carbon } \\
\text { payment initia- } \\
\text { tives in Nepal }\end{array}$ & $\begin{array}{l}\text { Human Ecol- } \\
\text { ogy, 42(5), } \\
683-694\end{array}$ & $\begin{array}{l}\text { Journal } \\
\text { Article }\end{array}$ & $\begin{array}{l}\text { Conflict/ } \\
\text { Moti- } \\
\text { vation }\end{array}$ & Meso & Both \\
\hline 49 & $\begin{array}{l}\text { Sikor, T., } \\
\text { and Cầm, } \\
\text { H }\end{array}$ & 2016 & $\begin{array}{l}\text { REDD+ on the } \\
\text { rocks? Conflict } \\
\text { over forest and } \\
\text { politics of jus- } \\
\text { tice in Vietnam }\end{array}$ & $\begin{array}{l}\text { Human Ecol- } \\
\text { ogy, 44(2), } \\
217-227\end{array}$ & $\begin{array}{l}\text { Journal } \\
\text { article }\end{array}$ & Conflict & Micro & $\begin{array}{l}\text { Target } \\
\text { group }\end{array}$ \\
\hline
\end{tabular}




\begin{tabular}{|c|c|c|c|c|c|c|c|c|}
\hline & Author(s) & Year & Title & Link/info & Type & Effect(s) & $\begin{array}{l}\text { Level } \\
\text { (micro, } \\
\text { meso, } \\
\text { macro) }\end{array}$ & $\begin{array}{l}\text { Target } \\
\text { group/ } \\
\text { other } \\
\text { groups }\end{array}$ \\
\hline 50 & $\begin{array}{l}\text { Sohngen, } \\
\text { B., and } \\
\text { Brown, S }\end{array}$ & 2004 & $\begin{array}{l}\text { Measuring leak- } \\
\text { age from carbon } \\
\text { projects in open } \\
\text { economies: a } \\
\text { stop timber har- } \\
\text { vesting project } \\
\text { in Bolivia as a } \\
\text { case study }\end{array}$ & $\begin{array}{l}\text { Canadian Jour- } \\
\text { nal of Forest } \\
\text { Research, 34(4), } \\
829-839\end{array}$ & $\begin{array}{l}\text { Journal } \\
\text { Article }\end{array}$ & Leakage & Micro & Other \\
\hline 51 & $\begin{array}{l}\text { Sunderlin, } \\
\text { W. D., } \\
\text { Larson, A. } \\
\text { M., Duch- } \\
\text { elle, A. E., } \\
\text { Resosu- } \\
\text { darmo, } \\
\text { I. A. P., } \\
\text { Huynh, } \\
\text { T. B., } \\
\text { Awono, } \\
\text { A., and } \\
\text { Dokken, T }\end{array}$ & 2014 & $\begin{array}{l}\text { How are REDD+ } \\
\text { proponents } \\
\text { addressing ten- } \\
\text { ure problems? } \\
\text { Evidence from } \\
\text { Brazil, Cam- } \\
\text { eroon, Tanzania, } \\
\text { Indonesia, and } \\
\text { Vietnam }\end{array}$ & $\begin{array}{l}\text { World Develop- } \\
\text { ment, 55, 37-52 }\end{array}$ & $\begin{array}{l}\text { Journal } \\
\text { article }\end{array}$ & $\begin{array}{c}\text { Indig- } \\
\text { enous } \\
\text { Peo- } \\
\text { ples }\end{array}$ & Meso & $\begin{array}{l}\text { Target } \\
\text { group }\end{array}$ \\
\hline 52 & $\begin{array}{l}\text { van Noord- } \\
\text { wijk, M., } \\
\text { and Beria, } \\
\text { L }\end{array}$ & 2010 & $\begin{array}{l}\text { Principles for } \\
\text { fairness and } \\
\text { efficiency in } \\
\text { enhancing } \\
\text { environmental } \\
\text { services in Asia: } \\
\text { payments, com- } \\
\text { pensation, or } \\
\text { co-investment? }\end{array}$ & $\begin{array}{l}\text { Ecology and Soci- } \\
\text { ety, 15(4) }\end{array}$ & $\begin{array}{l}\text { Journal } \\
\text { article }\end{array}$ & $\begin{array}{l}\text { Margin- } \\
\text { aliza- } \\
\text { tion }\end{array}$ & Meso & $\begin{array}{l}\text { Target } \\
\text { group }\end{array}$ \\
\hline 53 & $\begin{array}{l}\text { Vardhan, } \\
\text { M., and } \\
\text { Catacutan, } \\
\text { D }\end{array}$ & 2017 & $\begin{array}{l}\text { Analyzing } \\
\text { gender and } \\
\text { social equity in } \\
\text { payments for } \\
\text { environmen- } \\
\text { tal services } \\
\text { projects: lessons } \\
\text { from Southeast } \\
\text { Asia and East } \\
\text { Africa }\end{array}$ & $\begin{array}{l}\text { Co-investment } \\
\text { in ecosystem } \\
\text { services: global } \\
\text { lessons from pay- } \\
\text { ment and incentive } \\
\text { schemes. Nairobi, } \\
\text { Kenya: World } \\
\text { Agroforestry Cen- } \\
\text { tre (ICRAF) }\end{array}$ & Paper & $\begin{array}{l}\text { Margin- } \\
\text { aliza- } \\
\text { tion }\end{array}$ & Meso & $\begin{array}{l}\text { Target } \\
\text { group }\end{array}$ \\
\hline 54 & Wright, G & 2011 & $\begin{array}{l}\text { Indigenous people } \\
\text { and customary } \\
\text { land ownership } \\
\text { under domestic } \\
\text { REDD + frame- } \\
\text { works: A } \\
\text { case study of } \\
\text { Indonesia }\end{array}$ & $\begin{array}{l}\text { Law Env't and Dev. } \\
\text { J., } 7,117\end{array}$ & $\begin{array}{l}\text { Journal } \\
\text { article }\end{array}$ & $\begin{array}{l}\text { Indig- } \\
\text { enous } \\
\text { peo- } \\
\text { ples }\end{array}$ & Micro & $\begin{array}{l}\text { Target } \\
\text { group }\end{array}$ \\
\hline
\end{tabular}




\begin{tabular}{|c|c|c|c|c|c|c|c|c|}
\hline & Author(s) & Year & Title & Link/info & Type & Effect(s) & $\begin{array}{l}\text { Level } \\
\text { (micro, } \\
\text { meso, } \\
\text { macro) }\end{array}$ & $\begin{array}{l}\text { Target } \\
\text { group/ } \\
\text { other } \\
\text { groups }\end{array}$ \\
\hline 55 & $\begin{array}{l}\text { Yanez- } \\
\text { Pagans, P }\end{array}$ & 2013 & $\begin{array}{l}\text { Cash for coopera- } \\
\text { tion? Payments } \\
\text { for Ecosystem } \\
\text { Services and } \\
\text { common prop- } \\
\text { erty manage- } \\
\text { ment in Mexico }\end{array}$ & $\begin{array}{l}\text { https://ageconsear } \\
\text { ch.umn.edu/ } \\
\text { record/15129 } \\
\text { 4/files/Paper } \\
\text { _AAEA_06031 } \\
\text { 3.pdf }\end{array}$ & Paper & $\begin{array}{l}\text { Motiva- } \\
\text { tion }\end{array}$ & Meso & $\begin{array}{l}\text { Target } \\
\text { group }\end{array}$ \\
\hline 56 & $\begin{array}{l}\text { Zhang, Q., } \\
\text { Bilsbor- } \\
\text { row, R. } \\
\text { E., Song, } \\
\text { C., Tao, } \\
\text { S., and } \\
\text { Huang, Q }\end{array}$ & 2018 & $\begin{array}{l}\text { Determinants of } \\
\text { out-migration } \\
\text { in rural China: } \\
\text { effects of } \\
\text { payments for } \\
\text { ecosystem } \\
\text { services }\end{array}$ & $\begin{array}{l}\text { Population and Envi- } \\
\text { ronment, } 40(2) \text {, } \\
\text { 182-203 }\end{array}$ & $\begin{array}{l}\text { Journal } \\
\text { article }\end{array}$ & $\begin{array}{l}\text { Migra- } \\
\text { tion }\end{array}$ & Meso & $\begin{array}{l}\text { Target } \\
\text { group }\end{array}$ \\
\hline 57 & $\begin{array}{l}\text { Zhang, Q., } \\
\text { Song, C., } \\
\text { and Chen, } \\
\text { X. (2018) }\end{array}$ & 2018 & $\begin{array}{l}\text { Effects of China's } \\
\text { payment for } \\
\text { ecosystem ser- } \\
\text { vices programs } \\
\text { on cropland } \\
\text { abandonment: } \\
\text { A case study in } \\
\text { Tiantangzhai } \\
\text { Township, } \\
\text { Anhui, China }\end{array}$ & $\begin{array}{l}\text { Land use policy, } 73 \text {, } \\
\text { 239-248 }\end{array}$ & $\begin{array}{l}\text { Journal } \\
\text { Article }\end{array}$ & $\begin{array}{l}\text { Migra- } \\
\text { tion }\end{array}$ & Meso & $\begin{array}{l}\text { Target } \\
\text { group }\end{array}$ \\
\hline
\end{tabular}

\section{Appendix 2: Overview of policy documents}

\section{BIO carbon fund}

BIO Carbon Fund (2011). BIO Carbon Fund Experience-Insights from Afforestation and Reforestation Clean Development Mechanism Projects. World Bank, Washington, DC.

BIO Carbon Fund (2017). Initiative for Sustainable Forest Landscapes: Emission Reduction (ER) Program Requirements. World Bank, Washington, DC.

BIO Carbon Fund (2018). BIO Carbon Fund Initiative for Sustainable Forest Landscapes Annual Report 2018. World Bank, Washington, DC.

BIO Carbon Fund (2019). BIO Carbon Fund Initiative for Sustainable Forest Landscapes-First Program Evaluation Final Report. World Bank, Washington, DC.

BIO Carbon Fund (2019). Monitoring, Evaluation and Learning (MEL) Frameworkversion 2019. World Bank, Washington, DC.

BIO Carbon Fund (2017). BIO Carbon Fund Initiative for Sustainable Forest Landscapes-Emission Reductions (ER) Program Document (PD) Template. World Bank, Washington, DC. 


\section{Forest carbon partnership facility}

Baastel and NORDECO (2011). First Program Evaluation for the Forest Carbon Partnership Facility (FCPF). World Bank, Washington, DC.

Forest Carbon Partnership Facility (n.d.). Carbon Fund Steps: From Project Idea Notes (ER-PINs) to Payment Agreements (ERPAs). World Bank, Washington, DC. https:// Www.forestcarbonpartnership.org/carbon-fund.

Forest Carbon Partnership Facility (n.d.). Readiness Fund REDD+ Country Participants Progress Report Template. World Bank, Washington, DC.

Forest Carbon Partnership Facility. (sd). Capacity Building Program for Indigenous Peoples and Civil Society. Opgehaald van https://www.forestcarbonpartnership.org/ capacity-building-program.

Forest Carbon Partnership Facility Participants Committee (2012). FMT Note 2012-8, Recommendations of the Working Group on the Methodological and Pricing Approach for the Carbon Fund of the FCPF. World Bank, Washington, DC.

Forest Carbon Partnership Facility (2016). Carbon Fund methodological framework. World Bank, Washington, DC.

Forest Carbon Partnership Facility. (2016). Revised Emmission Reduction Program Document Lac Mai Ndombe DR Congo.

Forest Carbon Partnership Facility (2017). FCPF Readiness Fund Completion Report (Mozambique). World Bank, Wanshington, DC.

Forest Carbon Partnership Facility (2018). FCPF Readiness Fund: REDD+ Country Participant Annual Progress Report (Mozambique). World Bank, Washington, DC.

Forest Carbon Parternship Facility. (2018). Advanced Draft Benefit Sharing Plan of Mai-Ndombe Emission Reductions Program in the Democratic Republic of Congo. Worldbank.

Indufor... Forest Intelligence (2016). Second Evaluation of the Forest Carbon Partnership Facility. Helsinki, Finland.

República de Moçambique Ministerio da Terra, Ambiente e Desenvolvimiento Rural (2017). Environmental and Social Management Framework (ESMF) for (i) the Mozambique Forest Investment Project (MozFIP), (ii) the Dedicated Grant Mechanism to Local Communities (MozDGM) and (iii) REDD+ Initiatives.

República de Moçambique Ministerio da Terra, Ambiente e Desenvolvimiento Rural (2017). Strategic Environmental and Social Assessment.

República de Moçambique Ministerio da Terra, Ambiente e Desenvolvimiento Rural (2017). R-Package Multi-stakeholder Self-Assessment of REDD+ Readiness in Mozambique.

Riamit, K. O. (2019). Weilburg Conference II: Social Inclusion in REDD+ processes: Status and Achievements of 10 years' REDD+ Preparation and Implementation. Washington, DC: Forest Carbon Partnership Facility.

World Bank (2011). World Bank Management Response to the FCPF Evaluation Report. World Bank, Washington, DC.

World Bank. (2019). Concept Environmental and Social Review Summary-Concept stage. 


\section{Green climate fund}

Green Climate Fund (n.d.). Green Climate Fund Results Based Payments Program Proposal Template. Green Climate Fund, Incheon, South Korea.

Green Climate Fund (2017). GCF/B.17/16-Green Climate Fund support for the early phases of REDD-plus. Green Climate Fund, Incheon, South Korea.

Green Climate Fund (2018). Environmental and Social Policy. Green Climate Fund, Incheon, South Korea.

Green Climate Fund (2018). GCF/B.19/05-Indigenous Peoples Policy. Green Climate Fund, Incheon, South Korea.

Green Climate Fund (2018). Readiness and Preparatory support guidebook. Green Climate Fund, Incheon, South Korea.

Green Climate Fund (2019). Green Climate Fund Working Paper no. 2: Accelerating REDD+ Implementation. Green Climate Fund, Incheon, South Korea.

\section{Other}

Forest Carbon Partnership Facility (2013). FMT Note CF-2013-3-World Bank Safeguard Policies and the UNFCCC REDD+ Safeguards. World Bank, Washington, DC. United Nations (2011). FCCC/CP/2010/7/Add.1 Framework Convention on Climate Change.

UNREDD (n.d.). Safeguards. Accessed 15 June 2019: https://www.unredd.net/knowl edge/redd-plus-technical-issues/safeguards.html.

World Bank (2017). The World Bank Environmental and Social Framework. World Bank, Washington, DC.

\section{Appendix 3: Key informant interviews}

Interview 1: Worldbank/Consultant for climate change, forests and sustainable landscapes, 5 July 2019.

Interview 2: Fund manager, Worldbank/Forest Carbon Partnership Facility, 19 August 2019.

Interview 3: Worldbank/Coordinator, Forest Carbon Partnership Facility and Bio Climate Fund Initiative for Sustainable Forest Landscapes, 19 August 2019.

Interview 4: Climate and Forests for Development specialist, Green Climate Fund, 11 September 2019.

Interview 5: Consultant, Rights and Resources Initiative, 27 September 2019.

Interview 6: Policy Advisor on Nature, Fisheries and Rural Areas, Dutch Ministry of Agriculture, Nature and Food Quality, 1 October 2019.

Interview 7: Professor of Geoinformation Science and Remote Sensing, Wageningen University, 1 October 2019.

Interview 8: Senior Policy Officer, Dutch Ministry of Foreign Affairs, 10 October 2019

Interview 9: Coordinating Policy Officer, Dutch Ministry of Foreign Affairs, 10 October 2019

Interview 10: Director, Local NGO, UN Redd Monitoring Program, 10 October 2019 


\section{Appendix 4: Methodology for structured literature review}

For the structured literature review we used Google Scholar, searching with the keywords outlined below with AND inserted between the keywords. On the basis of the relevance of the title and abstract of the first 100 hits of each search combination, relevant articles, books and papers were selected and read.

As a significant body of research on the unintended effects of international cooperation has emerged in recent years, some of this literature was consulted to acquire the most relevant search terms for this literature review. An unintended consequence, according to the sociological functionalist school, refers to "a particular effect of purposive action, which is different from what was wanted at the moment of carrying out the act" (Baert 2016). Although there is a theoretical discussion on whether unintended should be replaced by unanticipated, to distinguish from effects which are unintended but anticipated (Zwart 2015), we used both terms in our key-word search. To ensure capturing all relevant research, we also used unplanned, unexpected, and unforeseen. Moreover, instead of effects, we entered consequences, results, outcomes and impacts to our key-word searches.

As this research focuses on the unintended effects of Payment for Environmental Services (PES), this term was also part of the key-word search. One of the most-used definitions of PES is Wunder's, who asserts that PES is “(1) a voluntary transaction in which (2) a well-defined environmental service (or a land use likely to secure that service) (3) is 'bought' by a (minimum of one) buyer (4) from a (minimum of one) provider (5) if and only if the provider continuously secures the provision of the service (conditionality)" (Wunder et al. 2008, p. 50). Although there are critiques to this definition, this is the most widely cited one and we use it as a theoretical reference point.

The consulted literature introduced some equivalent terms: Payment for Ecosystem Services and Payment for Ecological Services were also introduced into the search strings, to make sure all relevant research would be covered. In addition, as we have a particular interest in PES of the forest-conservation type, Payment for Forest Conservation was also added, as was REDD+: the UN programme on "Reducing Emissions from Deforestation and forest Degradation in developing countries".

The quality of the study (analytical, methodological, empirical) was not an exclusion criterion, as our aim was to find effects that were reasonably substantiated through research rather than conducting a quality analysis of the studies. Although reviews were not included in the selection for analysis, their bibliographies were analysed to find additional primary research that had not come up in our initial searches. Furthermore, after the results of this search strategy had been analysed and clustered into groups, additional searches were carried out to find literature which dealt with these effects but did not label them as unintended or unanticipated.

Studies focusing on unintended but positive effects were excluded, as they are irrelevant for the second section of this paper, which analyses PES implementers' anticipation and mitigation measures and their learning. This is only relevant for negative effects. Lastly, although studies were generally excluded if they were not relevant to forest conservation PES, some effects found in other types of PES (such as watershed services or fisheries) were included if these effects could also be relevant to forest conservation programmes. The motivation crowding effect, one of the most commonly found effects in this search, is one such example. 


\section{References}

Alix-Garcia, J. M., Shapiro, E. N., \& Sims, K. R. (2012). Forest conservation and slippage: Evidence from Mexico's national payments for ecosystem services program. Land Economics, 88(4), 613-638.

Alpízar, F., Nordén, A., Pfaff, A., \& Robalino, J. (2017). Unintended effects of targeting an environmental rebate. Environmental and Resource Economics, 67(1), 181-202.

Andrews, J. (2018). Cultural group selection and the design of REDD+: Insights from Pemba. Sustainability Science, 13(1), 93-107.

Asbjornsen, H., Manson, R. H., Scullion, J. J., Holwerda, F., Muñoz-Villers, L. E., Alvarado-Barrientos, M. S., \& Bruijnzeel, L. A. (2017). Interactions between payments for hydrologic services, landowner decisions, and ecohydrological consequences: Synergies and disconnection in the cloud forest zone of central Veracruz, Mexico. Ecology and Society, 22(2).

Atmadja, S. (2012). A review of the state of research, policies and strategies in addressing leakage from reducing emissions from deforestation and forest degradation (REDD+). Mitigation and Adaptation Strategies for Global Change, 17(3), 311-336.

Baert, P. (2016). Unintended consequences: a typology and examples. International Sociology, 6(2), 201-210.

Bayrak, M. M., \& Marafa, L. M. (2016). Ten years of REDD+: A critical review of the impact. Sustainability, 8, 620-642.

Bowles, S., \& Polania-Reyes, S. (2012). Economic incentives and social preferences: Substitutes or complements? Journal of Economic Literature, 50(2), 368-425.

Brusset, E., De Coning, C., \& Hughes, B. (2016). Complexity thinking for peacebuilding practice and evaluation. London: Palgrave Macmillan.

Burlyuk, O., \& Noutcheva, G. (2019). Unintended consequences of EU external action. The International Spectator, 54(1), 1-15.

Corbera, E., Brown, K., \& Adger, W. N. (2007). The equity and legitimacy of markets for ecosystem services. Development and change, 38(4), 587-613.

Cotula, L., \& Mayers, J. (2009). Tenure in REDD: Start-point or afterthought? Natural Resources issues No. 15. London: International Institute for Environment and Development (IIED).

de Francisco, J., \& Boelens, R. (2014). Payment for environmental services and power in the Chamachán watershed, Ecuador. Human Organization, 73(4), 351-362.

de Zwart, F. (2015). Unintended but not unanticipated. Theory and Society, 44(3), 283-297.

Démurger, S., \& Wan, H. (2012). Payments for ecological restoration and internal migration in China: The sloping land conversion program in Ningxia. IZA Journal of Migration, 1(1), 10.

Duchelle, A., Simonet, G., Sunderlin, W., \& Wunder, S. (2018). What is REDD+ achieving on the ground? Current Opinion in Environmental Sustainability, 32, 134-140.

Easterly, W. (2001). The elusive quest for growth. Econimists' adventures and misadventures in the tropics. Cambridge: MIT Press.

Easterly, W. (2006). Planners versus the searchers in foreign aid. Asian Development Review, 6, 1-36.

Eising, R. (2000). Bounded rationality and policy learning in EU negotiations. EIU Working Paper RSC 2000/26.

Erazo, J. S. (2013). REDD: Development opportunity or neoliberal threat? Indigenous organizations take opposing views. NACLA Report on the Americas, 46(1), 55-60.

Ezzine-de-Blas, D., Wunder, S., Ruiz-Pérez, M., \& del Pilar Moreno-Sanchez, R. (2016). Global patterns in the implementation of payments for environmental services. PLoS ONE, 11(3), e0149847.

García-Amado, L. R. (2013). Motivation for conservation: Assessing integrated conservation and development projects and payments for environmental services in La Sepultura Biosphere Reserve, Chiapas, Mexico. Ecological Economics, 89, 92-100.

Gauthier, M. (2018). Mai-Ndombe: Will the REDD+ laboratory benefit indigenous peoples and local communities. Washington, DC: Rights and Resources Institute.

Gong, Y., Bull, G., \& Baylis, K. (2010). Participation in the world's first clean development mechanism forest project: the role of property rights, social capital and contractual rules. Ecological Economics, 69(6), 1292-1302.

Green Climate Fund. (2017). Terms of reference for the pilot programme for REDD+ results-based payments. Incheon: Green Climate Fund.

Green Climate Fund. (2018). Environmental and social policy. Green climate fund, Incheon, South Korea. Retrieved July 14, 2019, from https://www.greenclimate.fund/sites/default/files/document/environmen t-social-policy.pdf.

Griffiths, T. (2007). Seeing 'REDD'. Avoided deforestation'and the rights of Indigenous Peoples and local communities'. Forest Peoples Programme, 26. 
Hite, K. (2015). Benefit sharing and REDD+: Considerations and options for effective design and operation. Washington, DC.: USAID-supported Forest Carbon, Markets and Communities.

Hovi, J., Sprinz, D., Sælen, H., \& Underdal, A. (2016). Climate change mitigation: A role for climate clubs? Palgrave Communications, 2, 16020. https://doi.org/10.1057/palcomms.2016.20.

Ibarra, J. T. (2011). When formal and market-based conservation mechanisms disrupt food sovereignty: Impacts of community conservation and payments for environmental services on an indigenous community of Oaxaca, Mexico. International Forestry Review, 13(3), 318-337.

Isyaku, U. (2017). Beyond policy design: REDD+ implementation and institutional complexities of environmental governance in Cross River state, Nigeria (Doctoral dissertation, University of Leicester).

Kerr, J. V. (2012). Prosocial behavior and incentives: Evidence from field experiments in rural Mexico and Tanzania. Ecological Economics, 73, 220-227.

Koch, D.-J., \& Burlyuk, O. (2019). Bounded policy learning? EU efforts to anticipate unintended consequences in conflict minerals legislation. Journal of European Public Policy, 26, 1-22.

Koch, D.-J., \& Kinsbergen, S. (2018). Exaggerating unintended effects? Competing narratives on the impact of conflict minerals regulation. Resources Policy, 57, 255-263.

Koch, D.-J., \& Schulpen, L. (2018). Introduction to the special issues ' unintended effects of international cooperation'. Evaluation and Program Planning, 68, 202-209.

Krause, T. C. (2013). Evaluating safeguards in a conservation incentive program: Participation, consent, and benefit sharing in indigenous communities of the Ecuadorian Amazon. Ecology and Society, 18(4), 1-16.

Lansing, D. M. (2014.) Unequal access to payments for ecosystem services: The case of Costa Rica. Development and Change, 45(6), 1310-1331.

Mahanty, S., Dressler, W., Milne, S., \& Filer, C. (2013). Unravelling property relations around forest carbon. Singapore Journal of Tropical Geography, 34(2), 188-205.

Mayers, J. B. (2006). Forest governance and social justice: practical tactics from a learning group approach in Africa. International Forestry Review, 8(2), 201-210.

Merton, R. K. (1936). The unanticipated consequences of purposive social action. American Sociological Review, 1(6), 894-904.

Morell, J. A. (2010). Evalation in the face of uncertainty. New York: Guildford Press.

Mwangi, O. (2007). Hydropolitics, ecocide and human security in lesotho: A case study of the lesotho highlands water project. Journal of Southern African Studies, 33(1), 3-17.

Nordhaus, W. (2015). Climate clubs to overcome free-riding. Issues in Science and Technology, 31(4), 27-34.

Pokorny, B., Scholz, I., \& De Jong, W. (2013). REDD+ for the poor or the poor for REDD+? About the limitations of environmental policies in the Amazon and the potential of achieving environmental goals through pro-poor policies. Ecology and Society, 18(2).

Radaelli, C. (2009). Measuring policy learning: Regulatory impact assesment in Europe. Journal of European Public Policy, 16, 1145-1164.

Reed, P. (2011). REDD+ and the indigenous question: A case study from Ecuador. Forests, 2(2), 525-549.

ReddMonitor. (2011). REDD: An introduction. Retrieved April 8, 2019, from https://redd-monitor.org/reddan-introduction/:ReddMonitor.

Riamit, K. O. (2019). Weilburg conference II: Social inclusion in REDD+ processes: Status and achievements of 10 years' REDD+ preparation and implementation. Washington, DC: Forest Carbon Partnership Facility.

Ros-Tonen, M. A., Reed, J., \& Sunderland, T. (2018). From synergy to complexity: The trend toward integrated value chain and landscape governance. Environmental Management, 62(1), 1-14.

Sabatier, P. (1988). An advocacy coalition framework of policy change and the role of policy-oriented learning therein. Policy Sciences, 21, 129-168.

Saito-Jensen, M., Rutt, R. L., \& Chhetri, B. B. K. (2014). Social and environmental tensions: affirmative measures under REDD+ carbon payment initiatives in Nepal. Human Ecology, 42(5), 683-694.

Sikor, T., \& Cầm, H. (2016). REDD+ on the rocks? Conflict over forest and politics of justice in Vietnam. Human Ecology, 44(2), 217-227.

United Nations Framework Convention on Climate Change. (2011). FCCC/CP/2010/7/Add.1.

United Nations Framework Convention on Climate Change. (2018). Summary and recommendations by the Standing Committee on Finance on the 2018 Biennial Assessment and Overview of Climate Finance Flows. Retrieved May 14, 2019, from https://unfccc.int/sites/default/files/resource/51904\%2520\%2520UNFCCC\%2520BA\%25202018\%2520-\%2520Summary\%2520Final.pdf.

Vardhan, M., \& Catacutan, D. (2017). Analyzing gender and social equity in payments for environmental services projects: lessons from Southeast Asia and East Africa. In Co-investment in ecosystem 
services: Global lessons from payment and incentive schemes. World agroforestry centre (ICRAF) Nairobi.

World Bank BIO Carbon Fund. (2011). BioCarbon fund experience: Insights from aforestation and reforestation clean development mechanism projects. Washington, DC: World Bank Group.

World Bank BIO Carbon Fund. (2017). ISFL emission reductions (ER) program document (PD) template. Washington, DC: World Bank Group.

World Bank Forest Carbon Partnership Facility. (2013). FMT note CF-2013-3_World bank safeguard policies and the UNFCCC REDD+ safeguards. Washington, DC: World Bank Group.

World Bank Forest Carbon Partnership Facility. (2016). FCPF carbon fund methodological framework. Washington, DC: World Bank Group.

World Bank Group. (2017). Environmental and social safeguards. Washington, DC: World Bank Group.

Wunder, S., Engel, S., \& Pagiola, S. (2008). Taking stock: A comparative analysis of payments for environmental services programs in developed and developing countries. Ecological Economics, 65(4), 834-852.

Zhang, Q., Song, C., \& Chen, X. (2018). Effects of China's payment for ecosystem services programs on cropland abandonment: A case study in Tiantangzhai Township, Anhui, China. Land use policy, 73, 239-248.

Publisher's Note Springer Nature remains neutral with regard to jurisdictional claims in published maps and institutional affiliations. 